\author{
トキサフェンの環境動態と \\ ガスクロマトグラフィー/質量分析法による定量 \\ 高澤 嘉一, 柴田 康行, 森田 昌敏 \\ 国立環境研究所（テ305-8506 茨城県つくば市小野川16-2） \\ [平成14年12月17日受理］
}

\title{
Environmental Dynamics of Toxaphene and Its Determination by Gas Chromatography-Mass Spectrometry
}

\author{
Yoshikatsu TAKAZAWA, Yasuyuki SHIBATA and Masatoshi MORITA \\ National Institute for Environmental Studies \\ (16-2 Onogawa, Tsukuba, Ibaraki 305-8506)
}

[Received December 17, 2002]

\begin{abstract}
Summary
Up to now, toxaphene has not been registered in Japan as agricultural chemicals. The chemical is one of persistent organic pollutants (POPs), therefore, there is a trend of internationally controlling. In this paper, information on persistency of toxaphene and global polluted situations were arranged. Determination by gas chromatography-mass spectrometry (GC-MS) was also described. The composition of toxaphene, which persisted in the environment, was remarkably different from original technical toxaphene with the passage of time. For example, the main pathway of decomposition in soil was reductive dechlorination. Specific congeners in human milk were B8-1413 and B9-1679. It was thought that the congeners had strong persistency due to a stable bornane skeleton having no strain in sixmembered ring. Problems in GC-MS were as follows. Toxaphene was thermally much less stable; electron impact ionization caused complex fragmentation; and each congener varied extremely in the relative response factor using negative ion chemical ionization. In the future, the establishment of analytical system having the advantage of accuracy and of precision requires selective separation of enantiomers and synthesis of standard substances.
\end{abstract}

Key words: toxaphene, POPs, GC-MS

\section{1.はじめに}

トキサフェンは塩素化ボルナン, 塩素化ボルネン, 塩 素化カンフェンなど複数の成分から構成される化学物質 であり, 主要成分は 6 塩素化から10塩素化までのボルナ ンおよびボルネンと言われている ${ }^{1-6)}$ 。各成分に含まれる 異性体数も極めて多く, 塩素化ボルナンにのみ限定して
も理論的には32,768種の異性体が存在する7。現在まで に工業用トキサフェンを用いて判明されている異性体は 670 種以上であり ${ }^{8}$, 特に 5 塩素化から 12 塩素化までの ボルナンは，そのほとんどが確認されている9”。1945年 にアメリカ合衆国の Hercules 社にてカンフェンの触媒 塩素化を行うことにより初めて製造され(1), Hercules $3956^{\circledR}$ などの品名（Table 1) で本格的な流通が始まる ${ }^{10}$ 
Table 1 Trade names of toxaphene

\begin{tabular}{lllllll}
\hline Trade names & & & & & Common names \\
\hline Allotox & Cristoxo-90 & Geniphene & Morox & Synthetic 3956 & Toxaspra & Toxaphene \\
Attac & Dark & Gy-phene & Penphene & Toxadust & Toxon 63 & Camphechlor \\
Chem-Phene & Delicia Fribal & Hercules 3956 & Phenacide & Toxadust 10 & Vapotone & Chlorinated camphene \\
Chlor Chem T-590 & Estonox & Huileux & Phenatox & Toxakil & & Octachlorocamphene \\
Chlorter & Fasco Terpene & Melipax & Strobane-T & Toxyphen & & Polychlorocamphene \\
\hline
\end{tabular}

と急速に全世界へ普及した。当時の主な用途は, 池や湖 に棲息し生態系を乱す恐れのある外来魚の駆除あるいは 綿花や大豆など農作物に対する害虫防除1-13)であった。 特に農作物への使用は世界各地で行われており, 西ドイ ツやポーランドではキャベッに25)，旧ソビエト連邦やハ ンガリーでは綿花やアルファルファに24,26,27)，メキシコ ではとうもろこし ${ }^{23}$ に対して使用されていた。また，中 央アジアではディーゼル燃料の溶媒中に含まれていたと の報告 ${ }^{16)}$ あることから，Voldner らは，このような一種 の代替的な使用が他の国々でもあったのではないか子 推測している。

トキサフェンの使用量と生産量について，若干の知見 が得られている。1950年から 1993年の間で，地球規模で のトキサフェンの使用量は1,330,000トンと見積られ， 旧ソビエト連邦では1970年以来100,000トンが使用され たとの報告 ${ }^{23}$ がある。エジプトでは1961年に使用禁止と なったが1956年から1961年に至るまでに54,000トン ${ }^{81)}$, メキシコでは1985年に600トン20，五大湖周辺では1970 年から1977年まで年間1,000トンの割合で使用されてい た ${ }^{14)}$ 。Barrieらは世界におけるトキサフェンの生産量を 700,000トンと見積り，アメリカ合衆国では1946年から

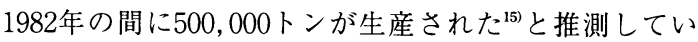
る。McConnell らは，1950年から1993年までの詳細な 生産量は不明としながらも，世界における生産量は 1,300,000トン ${ }^{16)}$ と報告している。このようにトキサ フェンは世界で最も汎用された農薬 ${ }^{15,28)}$ の一つとなり, 特に旧ソビエト連邦，アメリカ合衆国拉よびエジプトは その使用頻度と散布量が高い地域と思われる。このよう に汎用されたトキサフェンであるが，その毒性，環境 残留性, 蓄積性から生態への影響が懸念され始める $と^{10,17.18)}, 1982$ 年, トキサフェンの大量消費国であったア メリカ合衆国は在庫を除く国内における使用を規制し た。これに付随してイギリスやカナダなどの主要工業国

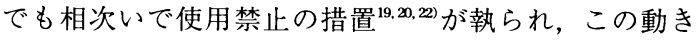
は急速に国際社会へ伝わった。そのため, 1980年代前半 以降, 一部の国々 (メキシコ, アルゼンチン) での限定 的使用を除いてほとんどの国々で使用されていない。
2001年，残留性有機污染物質（以下，POPs）に関する 国際条約がストックホルムにて採択された。この条約 は, POPs の使用や生産，排出を国際的に規制すること が目的でありトキサフェンも対象物質に含まれている。 これら POPsによる污染実態を国際的に調査すること は, 化学物質の長距離移動性の解明, 発生源の予測掠よ び日本国内の污染レベルを評価する際に有用である。こ こでは，POPsのなかでも日本国内での使用実績がない トキサフェンによる環境污染の実態調査を進める上で, その検討過程を通じて得られた知見を中心に環境中での 分解性や地球規模での污染状況に関する情報を総括し た。また，ガスクロマトグラフィー/質量分析法（以下， GC-MS）による定量操作とその際の留意点についても 併記した。

Table 2 および 3 に現在までに調査され報告されてい る環境中のトキサフェンの濃度を示す。各報告における データの濃度単位と表記について, LW は脂肪重量, DW は乾燥重量, WW は湿重量換算の濃度と定義する。

\section{2. 物理化学的性質}

トキサフェンは黄色のワックス状固体であり, 若干の テルペン臭を伴う。ほとんどの有機溶媒や脂質に溶解す るが, 脂肪族炭化水素よりも芳香族炭化水素に溶解しゃ すい傾向 ${ }^{80}$ が認められる。脱塩素化はアルカリおよび紫 外線の存在下あるいは $120^{\circ} \mathrm{C}$ 以上の温度条件により進行 する ${ }^{91)}$ と報告されている。Table 4 にその物理化学的性 質をまとめて示す。トキサフェン同族体のオクタノール/ 水分配係数（以下, $\log K_{\text {ow }}$ ) は塩素数との間で最も顕著

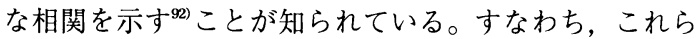
の諸量は塩素の配位部位や炭素骨格の構造により異性体 間で大きく変動する可能性がある。また極めて複雑な組 成であることから，工業用トキサフェンの組成は製造元 により異なることも十分に予測される。

トキサフェンの生成過程は次の通りである。（1）松 の切り株などから $\alpha$-pinene を抽出する。(2) $\alpha$-pinene のカンフェンへの異性化反応を行う。(3) 紫外線照射 によりカンフェンの塩素化を行う。このようにして得ら 
Table 2 Total toxaphene in abiotic samples

\begin{tabular}{|c|c|c|c|c|}
\hline Group & Location & Year & Concentration & Reference \\
\hline \multirow[t]{29}{*}{ Air } & Arctic & 1992 & $1.6-27 \mathrm{pg} / \mathrm{m}^{3}$ & 34 \\
\hline & Lake Baikal & 1991 & $16 \mathrm{pg} / \mathrm{m}^{3}$ & 16 \\
\hline & 16 States (USA) & 1972 & $8700 \mathrm{ng} / \mathrm{m}^{3}$ (Max.) & 13 \\
\hline & Greenville & 1981 & $9.1 \mathrm{ng} / \mathrm{m}^{3}$ (Max.) & 13 \\
\hline & St. Louis & 1981 & $1.7 \mathrm{ng} / \mathrm{m}^{3}$ (Max.) & 13 \\
\hline & Bridgeman & 1981 & $0.44 \mathrm{ng} / \mathrm{m}^{3}$ (Max.) & 13 \\
\hline & Beaver Island & 1981 & $0.14 \mathrm{ng} / \mathrm{m}^{3}$ (Max.) & 13 \\
\hline & Western North Atlantic Ocean & $1973-74$ & $1.6 \mathrm{ng} / \mathrm{m}^{3}$ (Max.) & 13 \\
\hline & \multirow[t]{10}{*}{ Northwest Alabama } & 1996/Jan & $8 \mathrm{pg} / \mathrm{m}^{3}$ & 55 \\
\hline & & 1996/Feb & $172-224 \mathrm{pg} / \mathrm{m}^{3}$ & 55 \\
\hline & & 1996/Mar & $135 \mathrm{pg} / \mathrm{m}^{3}$ & 55 \\
\hline & & 1996/Apr & $58 \mathrm{pg} / \mathrm{m}^{3}$ & 55 \\
\hline & & 1996/May & $113 \mathrm{pg} / \mathrm{m}^{3}$ & 55 \\
\hline & & 1996/June & $474-611 \mathrm{pg} / \mathrm{m}^{3}$ & 55 \\
\hline & & 1996/July & $121-545 \mathrm{pg} / \mathrm{m}^{3}$ & 55 \\
\hline & & 1996/Aug & $194 \mathrm{pg} / \mathrm{m}^{3}$ & 55 \\
\hline & & $1996 / \mathrm{Sep}$ & $284 \mathrm{pg} / \mathrm{m}^{3}$ & 55 \\
\hline & & $1996 /$ Oct & $75 \mathrm{pg} / \mathrm{m}^{3}$ & 55 \\
\hline & South Carolina & $1994-95$ & $190 \mathrm{pg} / \mathrm{m}^{3}$ & 51 \\
\hline & \multirow[t]{2}{*}{ Ice Island } & 1986 & $25-78 \mathrm{pg} / \mathrm{m}^{3}$ & 52 \\
\hline & & 1987 & $21-45 \mathrm{pg} / \mathrm{m}^{3}$ & 52 \\
\hline & \multirow[t]{2}{*}{ Sable Island } & $1988-89$ & $23 \mathrm{pg} / \mathrm{m}^{3}$ & 53 \\
\hline & & 1989 & $47 \mathrm{pg} / \mathrm{m}^{3}$ & 53 \\
\hline & \multirow[t]{2}{*}{ Point Petre } & 1992 & $1.5-10.0 \mathrm{pg} / \mathrm{m}^{3}$ & 47 \\
\hline & & $1995-97$ & $0.9-10.1 \mathrm{pg} / \mathrm{m}^{3}$ & 47 \\
\hline & Egbert & $1988-89$ & $\mathrm{ND}-580 \mathrm{pg} / \mathrm{m}^{3}$ & 48 \\
\hline & Green Bay & 1989 & $27-109 \mathrm{pg} / \mathrm{m}^{3}$ & 49 \\
\hline & Lower Lakes & 1990 & $14-65 \mathrm{pg} / \mathrm{m}^{3}$ & 49 \\
\hline & Eagle Harbour & $1996-97$ & $\mathrm{ND}-63 \mathrm{pg} / \mathrm{m}^{3}$ & 50 \\
\hline \multirow[t]{3}{*}{ Sediment } & Bering Sea & 1988 & $0.0003 \mu \mathrm{g} / \mathrm{g}: \mathrm{WW}$ & 35 \\
\hline & Nicaragua & 1995 & $1420 \mathrm{ng} / \mathrm{g}$ (Max.) : DW & 100 \\
\hline & Mississippi & $1987-88$ & $0.07-0.12 \mu \mathrm{g} / \mathrm{g}: \mathrm{WW}$ & 36 \\
\hline \multirow[t]{13}{*}{ Surface water } & Ambient surface water & $1980-82$ & $0.05 \mu \mathrm{g} / \mathrm{L}$ & 13 \\
\hline & Municipal Runoff & $1980-82$ & ND & 13 \\
\hline & Lake Baikal & 1991 & $64 \mathrm{pg} / \mathrm{L}$ & 27 \\
\hline & \multirow[t]{2}{*}{ Lake Michigan } & $1991-92$ & $0.13 \mathrm{ng} / \mathrm{L}$ & 99 \\
\hline & & $1994-96$ & $0.38 \mathrm{ng} / \mathrm{L}$ & 99 \\
\hline & \multirow[t]{2}{*}{ Lake Sperior } & $1991-92$ & $0.29 \mathrm{ng} / \mathrm{L}$ & 99 \\
\hline & & $1994-96$ & $1.12 \mathrm{ng} / \mathrm{L}$ & 99 \\
\hline & \multirow[t]{2}{*}{ Lake Huron } & 1991-92 & $0.16 \mathrm{ng} / \mathrm{L}$ & 99 \\
\hline & & $1994-96$ & $0.47 \mathrm{ng} / \mathrm{L}$ & 99 \\
\hline & \multirow[t]{2}{*}{ Lake Erie } & $1991-92$ & $0.079 \mathrm{ng} / \mathrm{L}$ & 99 \\
\hline & & $1994-96$ & $0.23 \mathrm{ng} / \mathrm{L}$ & 99 \\
\hline & \multirow[t]{2}{*}{ Lake Ontario } & $1991-92$ & $0.061 \mathrm{ng} / \mathrm{L}$ & 99 \\
\hline & & $1994-96$ & $0.17 \mathrm{ng} / \mathrm{L}$ & 99 \\
\hline Rain & Southern France & $?$ & $53 \mathrm{ng} / \mathrm{L}$ (Max.) & 13 \\
\hline
\end{tabular}


Table 3 Total toxaphene in biotic samples

\begin{tabular}{|c|c|c|c|c|c|c|}
\hline Group & Location & Species & Tissue & Year & Concentration & Reference \\
\hline \multirow[t]{32}{*}{ Bird } & Arizona & Bald eagle & egg & $1977-85$ & $40 \mathrm{ng} / \mathrm{g}: \mathrm{WW}$ & 44 \\
\hline & \multirow[t]{11}{*}{ Texas } & Laughing gull & whole & 1978 & $\mathrm{ND}-3000 \mathrm{ng} / \mathrm{g}: \mathrm{WW}$ & 38 \\
\hline & & Ringed-billed gull & whole & 1978 & $\mathrm{ND}-3000 \mathrm{ng} / \mathrm{g}: \mathrm{WW}$ & 38 \\
\hline & & Franklin's gull & whole & 1978 & $\mathrm{ND}-2000 \mathrm{ng} / \mathrm{g}: \mathrm{WW}$ & 38 \\
\hline & & Herring gull & whole & 1978 & ND & 38 \\
\hline & & Pied-billed grebe & whole & 1978 & ND & 38 \\
\hline & & Forster's tern & whole & 1978 & $1700 \mathrm{ng} / \mathrm{g}: \mathrm{WW}$ & 38 \\
\hline & & Great-tailed grackle & whole & 1978 & ND & 38 \\
\hline & & Red-winged blackbird & whole & 1978 & ND & 38 \\
\hline & & Laughing gull & whole & 1979 & $\mathrm{ND}-400 \mathrm{ng} / \mathrm{g}: \mathrm{WW}$ & 38 \\
\hline & & $?$ & muscle & $1965-88$ & $60-1700 \mathrm{ng} / \mathrm{g}: \mathrm{WW}$ & 45 \\
\hline & & Forster's tern (carcass) & $?$ & 1978 & $1700 \mathrm{ng} / \mathrm{g}: \mathrm{WW}$ & 45 \\
\hline & \multirow[t]{6}{*}{ Baltic Sea } & Guillemot & egg & 1974 & $13000 \mathrm{ng} / \mathrm{g}: \mathrm{LW}$ & 21 \\
\hline & & Guillemot & egg & 1976 & $14000-23000 \mathrm{ng} / \mathrm{g}: \mathrm{LW}$ & 21 \\
\hline & & Guillemot & egg & 1978 & $9500 \mathrm{ng} / \mathrm{g}: \mathrm{LW}$ & 21 \\
\hline & & Guillemot & egg & 1982 & $8000 \mathrm{ng} / \mathrm{g}: \mathrm{LW}$ & 21 \\
\hline & & Guillemot & egg & 1987 & $5200 \mathrm{ng} / \mathrm{g}: \mathrm{LW}$ & 21 \\
\hline & & Guillemot & egg & 1989 & $6100-15000 \mathrm{ng} / \mathrm{g}: \mathrm{LW}$ & 21 \\
\hline & \multirow[t]{8}{*}{ Norway } & Golden eagle & egg & $1991-97$ & $\mathrm{ND}-131 \mathrm{ng} / \mathrm{g}: \mathrm{WW}$ & 152 \\
\hline & & White-tailed sea eagle & egg & $1991-97$ & $\mathrm{ND}-243 \mathrm{ng} / \mathrm{g}: \mathrm{WW}$ & 152 \\
\hline & & Osprey & egg & $1991-97$ & $144-616 \mathrm{ng} / \mathrm{g}: \mathrm{WW}$ & 152 \\
\hline & & Merlin & egg & $1991-97$ & ND & 152 \\
\hline & & Gyrfalcon & egg & $1991-97$ & $\mathrm{ND}-21 \mathrm{ng} / \mathrm{g}: \mathrm{WW}$ & 152 \\
\hline & & Goshawk & egg & $1991-97$ & ND-136 ng/g : WW & 152 \\
\hline & & Peregrine falcon & egg & $1991-97$ & $\mathrm{ND}-32 \mathrm{ng} / \mathrm{g}: \mathrm{WW}$ & 152 \\
\hline & & Sparrow hawk & egg & $1991-97$ & $48-64 \mathrm{ng} / \mathrm{g}: \mathrm{WW}$ & 152 \\
\hline & \multirow[t]{6}{*}{ Trischen } & Seabird & egg & 1981 & $57 \mathrm{ng} / \mathrm{g}: \mathrm{WW}$ & 46 \\
\hline & & Seabird & egg & 1989 & $23 \mathrm{ng} / \mathrm{g}: \mathrm{WW}$ & 46 \\
\hline & & Seabird & egg & 1997 & $9 \mathrm{ng} / \mathrm{g}: \mathrm{WW}$ & 46 \\
\hline & & Seabird & egg & 1981 & $420 \mathrm{ng} / \mathrm{g}: \mathrm{LW}$ & 46 \\
\hline & & Seabird & egg & 1989 & $231 \mathrm{ng} / \mathrm{g}: \mathrm{LW}$ & 46 \\
\hline & & Seabird & egg & 1997 & $77 \mathrm{ng} / \mathrm{g}: \mathrm{LW}$ & 46 \\
\hline \multirow[t]{20}{*}{ Fish } & \multirow[t]{7}{*}{ Arctic Ocean } & Arctic cod & muscle & $1986-89$ & $50 \mathrm{ng} / \mathrm{g}$ (Max.) : WW & 37 \\
\hline & & Glacial eelpout & liver & $1986-89$ & $50 \mathrm{ng} / \mathrm{g}$ (Max.) : WW & 37 \\
\hline & & Arctic char & whole & $1986-89$ & $150 \mathrm{ng} / \mathrm{g}$ (Max.) : WW & 37 \\
\hline & & Inconnu & muscle & 1984 & $24 \mathrm{ng} / \mathrm{g}: \mathrm{WW}$ & 62 \\
\hline & & Pacific Herring & muscle & 1984 & $74 \mathrm{ng} / \mathrm{g}: \mathrm{WW}$ & 62 \\
\hline & & Arctic cod & muscle & 1984 & $23 \mathrm{ng} / \mathrm{g}: \mathrm{WW}$ & 62 \\
\hline & & Arctic cod & liver & 1989 & $540 \mathrm{ng} / \mathrm{g}: \mathrm{LW}$ & 63 \\
\hline & \multirow[t]{4}{*}{ Greenland } & Arctic cod & liver & 1994-95 & ND & 61 \\
\hline & & Shorthorn sculpin & liver & $1994-95$ & ND & 61 \\
\hline & & Arctic char & muscle & 1994-95 & $13 \mathrm{ng} / \mathrm{g}: \mathrm{WW}$ & 61 \\
\hline & & Atlantic salmon & whole & 1979 & $300 \mathrm{ng} / \mathrm{g}: \mathrm{WW}$ & 65 \\
\hline & Resolute Bay & Arctic cod & muscle & 1984 & $14 \mathrm{ng} / \mathrm{g}: \mathrm{WW}$ & 62 \\
\hline & Pangnirtung & Arctic cod & muscle & 1984 & $46 \mathrm{ng} / \mathrm{g}: \mathrm{WW}$ & 62 \\
\hline & Frobisher Bay & Greenland cod & whole & 1984 & $6 \mathrm{ng} / \mathrm{g}: \mathrm{WW}$ & 62 \\
\hline & Victoria Island & Greenland cod & muscle & 1984 & $<2 \mathrm{ng} / \mathrm{g}: \mathrm{WW}$ & 62 \\
\hline & \multirow[t]{5}{*}{ Georgia } & Antarctic cod & liver & 1977 & $220 \mathrm{ng} / \mathrm{g}: \mathrm{WW}$ & 26 \\
\hline & & Antarctic cod & liver & 1977 & $680 \mathrm{ng} / \mathrm{g}: \mathrm{LW}$ & 26 \\
\hline & & Spotted seatrout & ova & 1996 & $56 \mathrm{ng} / \mathrm{g}: \mathrm{LW}$ & 150 \\
\hline & & Atlantic croaker & ova & 1996 & $69 \mathrm{ng} / \mathrm{g}: \mathrm{LW}$ & 150 \\
\hline & & Southern flounder & liver & 1996 & $130 \mathrm{ng} / \mathrm{g}: \mathrm{LW}$ & 150 \\
\hline
\end{tabular}


Table 3 continued

\begin{tabular}{|c|c|c|c|c|c|c|}
\hline Group & Location & Species & Tissue & Year & Concentration & Reference \\
\hline \multirow[t]{52}{*}{ Fish } & Georgia & Red drum & liver & 1996 & $20 \mathrm{ng} / \mathrm{g}: \mathrm{LW}$ & 150 \\
\hline & \multirow[t]{2}{*}{ Caspian Sea } & Sturgeon & spawn & $1978-79$ & $304 \mathrm{ng} / \mathrm{g}: \mathrm{WW}$ & 26 \\
\hline & & Sturgeon & spawn & $1978-79$ & $1625 \mathrm{ng} / \mathrm{g}: \mathrm{LW}$ & 26 \\
\hline & \multirow[t]{2}{*}{ Drachensee } & Arctic char & spawn & 1978 & $17 \mathrm{ng} / \mathrm{g}: \mathrm{WW}$ & 26 \\
\hline & & Arctic char & spawn & 1978 & $125 \mathrm{ng} / \mathrm{g}: \mathrm{LW}$ & 26 \\
\hline & \multirow[t]{2}{*}{ Alaska } & Atlantic salmon & spawn & 1979 & $41 \mathrm{ng} / \mathrm{g}: \mathrm{WW}$ & 26 \\
\hline & & Atlantic salmon & spawn & 1979 & $285 \mathrm{ng} / \mathrm{g}: \mathrm{LW}$ & 26 \\
\hline & \multirow[t]{2}{*}{ Galway } & Atlantic salmon & spawn & 1979 & $260 \mathrm{ng} / \mathrm{g}: \mathrm{WW}$ & 26 \\
\hline & & Atlantic salmon & spawn & 1979 & $3500 \mathrm{ng} / \mathrm{g}: \mathrm{LW}$ & 26 \\
\hline & Ireland & Hake & liver & $?$ & $900 \mathrm{ng} / \mathrm{g}: \mathrm{WW}$ & 58 \\
\hline & \multirow[t]{11}{*}{ North Sea } & Twaite shad & liver & $1990-92$ & $20 \mathrm{ng} / \mathrm{g}: \mathrm{WW}$ & 30 \\
\hline & & Atlantic cod & liver & $1990-92$ & $600 \mathrm{ng} / \mathrm{g}$ (Max.) : WW & 30 \\
\hline & & Dab & liver & $1990-92$ & $10 \mathrm{ng} / \mathrm{g}$ (Max.) : WW & 30 \\
\hline & & Cod & liver & 1990 & $140 \mathrm{ng} / \mathrm{g}: \mathrm{WW}$ & 30 \\
\hline & & Cod & liver & 1991 & $580 \mathrm{ng} / \mathrm{g}: \mathrm{WW}$ & 30 \\
\hline & & Cod & liver & 1992 & $65 \mathrm{ng} / \mathrm{g}: \mathrm{WW}$ & 30 \\
\hline & & Haddock & liver & $1990-92$ & 430 ng/g (Max.) : WW & 30 \\
\hline & & Hake & liver & $1990-92$ & 1300 ng/g (Max.) : WW & 30 \\
\hline & & Spurdog & liver & $1990-92$ & $200 \mathrm{ng} / \mathrm{g}: \mathrm{WW}$ & 30 \\
\hline & & Twaite shad & fillet & $?$ & $20 \mathrm{ng} / \mathrm{g}: \mathrm{LW}$ & 58 \\
\hline & & Atlantic cod & liver & $?$ & $300 \mathrm{ng} / \mathrm{g}: \mathrm{WW}$ & 58 \\
\hline & \multirow[t]{2}{*}{ Southern North Sea } & Herring & muscle & 1989 & $400 \mathrm{ng} / \mathrm{g}: \mathrm{LW}$ & 66 \\
\hline & & Cod & liver & 1989 & $400 \mathrm{ng} / \mathrm{g}: \mathrm{LW}$ & 66 \\
\hline & Central North Sea & Cod & liver & 1989 & $600 \mathrm{ng} / \mathrm{g}: \mathrm{LW}$ & 66 \\
\hline & Northern North Sea & Cod & liver & 1989 & $1000 \mathrm{ng} / \mathrm{g}: \mathrm{LW}$ & 66 \\
\hline & German Bight & Plaice & liver & 1989 & $200 \mathrm{ng} / \mathrm{g}: \mathrm{LW}$ & 66 \\
\hline & \multirow[t]{2}{*}{ Teno River } & Atlantic salmon & muscle & 1988 & $2870 \mathrm{ng} / \mathrm{g}: \mathrm{LW}$ & 63 \\
\hline & & Atlantic salmon & muscle & 1990 & $890 \mathrm{ng} / \mathrm{g}: \mathrm{LW}$ & 63 \\
\hline & \multirow[t]{3}{*}{ Simo River } & Atlantic salmon & muscle & 1988 & $2580 \mathrm{ng} / \mathrm{g}: \mathrm{LW}$ & 63 \\
\hline & & Atlantic salmon & muscle & 1989 & $1370 \mathrm{ng} / \mathrm{g}: \mathrm{LW}$ & 63 \\
\hline & & Atlantic salmon & muscle & 1991 & 910 ng/g : LW & 63 \\
\hline & \multirow[t]{2}{*}{ Bothnian Sea } & Atlantic salmon & muscle & 1988 & $2010 \mathrm{ng} / \mathrm{g}: \mathrm{LW}$ & 63 \\
\hline & & Trout & muscle & $1990-91$ & $520 \mathrm{ng} / \mathrm{g}: \mathrm{LW}$ & 63 \\
\hline & Bothnian Bay & Trout & muscle & $1990-91$ & $1130 \mathrm{ng} / \mathrm{g}: \mathrm{LW}$ & 63 \\
\hline & \multirow[t]{6}{*}{ Baltic Sea } & Atlantic salmon & muscle & 1988 & $780 \mathrm{ng} / \mathrm{g}: \mathrm{LW}$ & 63 \\
\hline & & Cod & liver & 1988 & $640 \mathrm{ng} / \mathrm{g}: \mathrm{LW}$ & 63 \\
\hline & & Herring & muscle & 1978 & $13000 \mathrm{ng} / \mathrm{g}: \mathrm{LW}$ & 71 \\
\hline & & Salmon & muscle & $?$ & $16.2 \mathrm{ng} / \mathrm{g}: \mathrm{WW}$ & 142 \\
\hline & & Salmon & muscle & $?$ & $152 \mathrm{ng} / \mathrm{g}: \mathrm{LW}$ & 142 \\
\hline & & Herring & oil & 1989 & $7000 \mathrm{ng} / \mathrm{g}: \mathrm{LW}$ & 66 \\
\hline & Lake Saimaa & Atlantic salmon & muscle & 1988 & $7000 \mathrm{ng} / \mathrm{g}: \mathrm{LW}$ & 63 \\
\hline & Kokkola & Trout & muscle & 1991 & $1520 \mathrm{ng} / \mathrm{g}: \mathrm{LW}$ & 63 \\
\hline & \multirow[t]{8}{*}{ Texas } & Blue catfish & whole & 1978 & $9700-31500 \mathrm{ng} / \mathrm{g}: \mathrm{WW}$ & 38 \\
\hline & & Gizzard shad & whole & 1978 & $11200-29600 \mathrm{ng} / \mathrm{g}: \mathrm{WW}$ & 38 \\
\hline & & Sea catfish & whole & 1978 & ND-400 ng/g : WW & 38 \\
\hline & & Spotted seatrout & whole & 1978 & ND & 38 \\
\hline & & Blue catfish & whole & 1979 & $19500-24800 \mathrm{ng} / \mathrm{g}: \mathrm{WW}$ & 38 \\
\hline & & Gizzard shad & whole & 1979 & $5400 \mathrm{ng} / \mathrm{g}: \mathrm{WW}$ & 38 \\
\hline & & Channel catfish & whole & 1979 & $800-19500 \mathrm{ng} / \mathrm{g}: \mathrm{WW}$ & 38 \\
\hline & & Striped mullet & whole & 1979 & $4400 \mathrm{ng} / \mathrm{g}: \mathrm{WW}$ & 38 \\
\hline & \multirow[t]{2}{*}{ Skagerrak } & Herring & fillet & $?$ & $40 \mathrm{ng} / \mathrm{g}: \mathrm{WW}$ & 58 \\
\hline & & Plaice & muscle & 1989 & $100 \mathrm{ng} / \mathrm{g}: \mathrm{LW}$ & 66 \\
\hline
\end{tabular}


Table 3 continued

\begin{tabular}{|c|c|c|c|c|c|c|}
\hline Group & Location & Species & Tissue & Year & Concentration & Reference \\
\hline \multirow[t]{52}{*}{ Fish } & Bering Sea & Walleye pollock & whole & 1988 & $13 \mathrm{ng} / \mathrm{g}: \mathrm{WW}$ & 35 \\
\hline & Germany & Atlantic cod & liver oil & 1993 & $2450-2730 \mathrm{ng} / \mathrm{g}: \mathrm{LW}$ & 64 \\
\hline & Norway & Atlantic salmon & oil & 1993 & $540-1100 \mathrm{ng} / \mathrm{g}: \mathrm{LW}$ & 64 \\
\hline & \multirow[t]{3}{*}{ Bermudas } & Sixgill shark & whole & 1981 & $870 \mathrm{ng} / \mathrm{g}: \mathrm{LW}$ & 153 \\
\hline & & Oilfish & whole & 1981 & $475 \mathrm{ng} / \mathrm{g}: \mathrm{LW}$ & 153 \\
\hline & & Black grouper & whole & 1982 & $160 \mathrm{ng} / \mathrm{g}: \mathrm{LW}$ & 153 \\
\hline & Gulf of Mexico & Blacktip shark & whole & 1995 & ND & 153 \\
\hline & Gulf Stream & Menhaden & whole & 1997 & $12-25 \mathrm{ng} / \mathrm{g}: \mathrm{LW}$ & 153 \\
\hline & \multirow[t]{4}{*}{ North Pacific Ocean } & Halibut & muscle & $97-2001$ & $3-10 \mathrm{ng} / \mathrm{g}: \mathrm{LW}$ & 154 \\
\hline & & Halibut & liver & $97-2001$ & $40 \mathrm{ng} / \mathrm{g}: \mathrm{LW}$ & 154 \\
\hline & & Cod & liver & $97-2001$ & $11-105 \mathrm{ng} / \mathrm{g}: \mathrm{LW}$ & 154 \\
\hline & & Sand dad & liver & $97-2001$ & $9 \mathrm{ng} / \mathrm{g}: \mathrm{LW}$ & 154 \\
\hline & \multirow[t]{2}{*}{ Baffin Island } & Whitefish & muscle & 1995 & $890 \mathrm{ng} / \mathrm{g}: \mathrm{WW}$ & 138 \\
\hline & & Lake trout & muscle & 1995 & $2700 \mathrm{ng} / \mathrm{g}: \mathrm{WW}$ & 138 \\
\hline & \multirow[t]{7}{*}{ Yukon } & King salmon & ova & 1995 & $73-85 \mathrm{ng} / \mathrm{g}: \mathrm{WW}$ & 107 \\
\hline & & King salmon & flesh & 1995 & $60-143 \mathrm{ng} / \mathrm{g}: \mathrm{WW}$ & 107 \\
\hline & & Trout & flesh & 1995 & $206-219 \mathrm{ng} / \mathrm{g}: \mathrm{WW}$ & 107 \\
\hline & & Trout & liver & 1995 & $243 \mathrm{ng} / \mathrm{g}: \mathrm{WW}$ & 107 \\
\hline & & Whitefish & flesh & 1995 & $40 \mathrm{ng} / \mathrm{g}: \mathrm{WW}$ & 107 \\
\hline & & Ooligan & whole & 1995 & $155 \mathrm{ng} / \mathrm{g}: \mathrm{WW}$ & 107 \\
\hline & & Halibut & flesh & 1995 & $42 \mathrm{ng} / \mathrm{g}: \mathrm{WW}$ & 107 \\
\hline & \multirow[t]{4}{*}{ Gulf of St. Lawrence } & Herring & muscle & 1979 & $1000 \mathrm{ng} / \mathrm{g}: \mathrm{WW}$ & 60 \\
\hline & & Herring & muscle & 1979 & $12000 \mathrm{ng} / \mathrm{g}: \mathrm{LW}$ & 60 \\
\hline & & Atlantic cod & liver & 1979 & $1100 \mathrm{ng} / \mathrm{g}: \mathrm{WW}$ & 60 \\
\hline & & Atlantic cod & liver & 1979 & $2400 \mathrm{ng} / \mathrm{g}: \mathrm{LW}$ & 60 \\
\hline & \multirow[t]{2}{*}{ Halifax } & Herring & muscle & 1979 & $400 \mathrm{ng} / \mathrm{g}: \mathrm{WW}$ & 60 \\
\hline & & Herring & muscle & 1979 & $4400 \mathrm{ng} / \mathrm{g}: \mathrm{LW}$ & 60 \\
\hline & Labrador Sea & Atlantic salmon & whole & 1979 & $84 \mathrm{ng} / \mathrm{g}: \mathrm{WW}$ & 65 \\
\hline & \multirow[t]{5}{*}{ Siskiwit Lake } & Lake trout & whole & 1983 & $11000 \mathrm{ng} / \mathrm{g}: \mathrm{LW}$ & 54 \\
\hline & & Whitefish & whole & 1983 & $7000 \mathrm{ng} / \mathrm{g}: \mathrm{LW}$ & 54 \\
\hline & & Lake trout & whole & 1986 & $290 \mathrm{ng} / \mathrm{g}: \mathrm{WW}$ & 6 \\
\hline & & Whitefish & whole & 1986 & $220 \mathrm{ng} / \mathrm{g}: \mathrm{WW}$ & 6 \\
\hline & & Bay carp & whole & 1986 & $510 \mathrm{ng} / \mathrm{g}: \mathrm{WW}$ & 6 \\
\hline & \multirow[t]{2}{*}{ Lake Baikal } & Omul & whole & 1991 & $930-1300 \mathrm{ng} / \mathrm{g}: \mathrm{LW}$ & 27 \\
\hline & & Sculpin & whole & 1991 & $1600-2100 \mathrm{ng} / \mathrm{g}: \mathrm{LW}$ & 27 \\
\hline & Lake Tahoe & Lake trout & muscle & 1993-94 & $154 \mathrm{ng} / \mathrm{g}: \mathrm{WW}$ & 82 \\
\hline & \multirow[t]{5}{*}{ Mississippi } & Bowfin & whole & $1987-88$ & $300-8600 \mathrm{ng} / \mathrm{g}: \mathrm{WW}$ & 36 \\
\hline & & Common carp & whole & $1987-88$ & $500-6200 \mathrm{ng} / \mathrm{g}: \mathrm{WW}$ & 36 \\
\hline & & Mosquitofish & whole & $1987-88$ & $250 \mathrm{ng} / \mathrm{g}: \mathrm{WW}$ & 36 \\
\hline & & Smallmouth buffalo & whole & $1987-88$ & $800-15000 \mathrm{ng} / \mathrm{g}: \mathrm{WW}$ & 36 \\
\hline & & Spotted gar & whole & $1987-88$ & $2700 \mathrm{ng} / \mathrm{g}: \mathrm{WW}$ & 36 \\
\hline & \multirow[t]{6}{*}{ North Atlantic Ocean } & Atlantic cod & liver & $?$ & $270-780 \mathrm{ng} / \mathrm{g}: \mathrm{LW}$ & 39 \\
\hline & & Raw fish & oil & $?$ & $370-560 \mathrm{ng} / \mathrm{g}: \mathrm{LW}$ & 39 \\
\hline & & Refined fish & oil & $?$ & 97 ng/g (Max.) : LW & 39 \\
\hline & & Grenadier & whole & 1992 & $235-450 \mathrm{ng} / \mathrm{g}: \mathrm{LW}$ & 153 \\
\hline & & Halibut & whole & 1994 & $280 \mathrm{ng} / \mathrm{g}: \mathrm{LW}$ & 153 \\
\hline & & Halibut & whole & 1998 & $215 \mathrm{ng} / \mathrm{g}: \mathrm{LW}$ & 153 \\
\hline & \multirow[t]{4}{*}{ Nationwide (USA) } & Freshwater fish & whole & $1976-77$ & $340 \mathrm{ng} / \mathrm{g}: \mathrm{WW}$ & 40 \\
\hline & & Freshwater fish & whole & $1978-79$ & $280 \mathrm{ng} / \mathrm{g}: \mathrm{WW}$ & 40 \\
\hline & & Freshwater fish & whole & $1980-81$ & $280 \mathrm{ng} / \mathrm{g}: \mathrm{WW}$ & 40 \\
\hline & & Freshwater fish & whole & 1984 & $140 \mathrm{ng} / \mathrm{g}: \mathrm{WW}$ & 40 \\
\hline & Lake 625 ELA & Burbot & liver & $1985-86$ & $1720 \mathrm{ng} / \mathrm{g}: \mathrm{LW}$ & 72 \\
\hline
\end{tabular}


Table 3 continued

\begin{tabular}{|c|c|c|c|c|c|c|}
\hline Group & Location & Species & Tissue & Year & Concentration & Reference \\
\hline \multirow[t]{52}{*}{ Fish } & Lake Winnipeg & Burbot & liver & $1985-86$ & $810 \mathrm{ng} / \mathrm{g}: \mathrm{LW}$ & 72 \\
\hline & Trout Lake & Burbot & liver & $1985-86$ & $2340 \mathrm{ng} / \mathrm{g}: \mathrm{LW}$ & 72 \\
\hline & South Indian Lake & Burbot & liver & $1985-86$ & $1470 \mathrm{ng} / \mathrm{g}: \mathrm{LW}$ & 72 \\
\hline & Ft. Simpson & Burbot & liver & $1985-86$ & $1130 \mathrm{ng} / \mathrm{g}: \mathrm{LW}$ & 72 \\
\hline & Ft. G. Hope & Burbot & liver & $1985-86$ & $1570 \mathrm{ng} / \mathrm{g}: \mathrm{LW}$ & 72 \\
\hline & Arctic Red River & Burbot & liver & $1985-86$ & $1700 \mathrm{ng} / \mathrm{g}: \mathrm{LW}$ & 72 \\
\hline & Peel River & Burbot & liver & $1985-86$ & $930 \mathrm{ng} / \mathrm{g}: \mathrm{LW}$ & 72 \\
\hline & W. Davies Strait & Arctic char & whole & 1985 & $157 \mathrm{ng} / \mathrm{g}: \mathrm{WW}$ & 73 \\
\hline & Laberge Lake & Burbot & liver & $1990-92$ & $2810 \mathrm{ng} / \mathrm{g}: \mathrm{WW}$ & 74 \\
\hline & & Whitefish & muscle & $1990-92$ & $40 \mathrm{ng} / \mathrm{g}: \mathrm{WW}$ & 74 \\
\hline & & Lake trout & muscle & $1990-92$ & $657 \mathrm{ng} / \mathrm{g}: \mathrm{WW}$ & 74 \\
\hline & Kluane Lake & Burbot & liver & $1990-92$ & $54000 \mathrm{ng} / \mathrm{g}: \mathrm{WW}$ & 74 \\
\hline & Watson Lake & Whitefish & muscle & $1990-92$ & $<10 \mathrm{ng} / \mathrm{g}: \mathrm{WW}$ & 74 \\
\hline & & Lake trout & muscle & $1990-92$ & $<10 \mathrm{ng} / \mathrm{g}: \mathrm{WW}$ & 74 \\
\hline & Western Scheldt & Flounder & muscle & 1989 & $<150 \mathrm{ng} / \mathrm{g}: \mathrm{LW}$ & 66 \\
\hline & River Rhine & Eel & muscle & 1989 & $300 \mathrm{ng} / \mathrm{g}: \mathrm{LW}$ & 66 \\
\hline & Hollands Diep & Eel & muscle & 1989 & $300 \mathrm{ng} / \mathrm{g}: \mathrm{LW}$ & 66 \\
\hline & Meuse & Eel & muscle & 1989 & $300 \mathrm{ng} / \mathrm{g}: \mathrm{LW}$ & 66 \\
\hline & Yssel Lake & Eel & muscle & 1989 & $90 \mathrm{ng} / \mathrm{g}: \mathrm{LW}$ & 66 \\
\hline & Lake Xolotlan & Guapote & muscle & 1991 & $51 \mathrm{ng} / \mathrm{g}: \mathrm{WW}$ & 75 \\
\hline & & Tilapia & muscle & 1991 & $40 \mathrm{ng} / \mathrm{g}: \mathrm{WW}$ & 75 \\
\hline & Lake Michigan & Lake trout & belly & 1982 & $4300 \mathrm{ng} / \mathrm{g}: \mathrm{WW}$ & 76 \\
\hline & & Lake trout & whole & 1982 & $5000 \mathrm{ng} / \mathrm{g}: \mathrm{WW}$ & 77 \\
\hline & & Lake trout & whole & 1982 & $27000 \mathrm{ng} / \mathrm{g}: \mathrm{LW}$ & 77 \\
\hline & & Lake trout & whole & $1992-94$ & $1500 \mathrm{ng} / \mathrm{g}: \mathrm{WW}$ & 77 \\
\hline & & Lake trout & whole & $1992-94$ & $7600 \mathrm{ng} / \mathrm{g}: \mathrm{LW}$ & 77 \\
\hline & & Rainbow smelt & whole & 1982 & $740 \mathrm{ng} / \mathrm{g}: \mathrm{WW}$ & 77 \\
\hline & & Rainbow smelt & whole & 1982 & $10000 \mathrm{ng} / \mathrm{g}: \mathrm{LW}$ & 77 \\
\hline & & Rainbow smelt & whole & $1992-94$ & $59 \mathrm{ng} / \mathrm{g}: \mathrm{WW}$ & 77 \\
\hline & & Rainbow smelt & whole & $1992-94$ & $1100 \mathrm{ng} / \mathrm{g}: \mathrm{LW}$ & 77 \\
\hline & & Lake trout & whole & 1985 & $2800-6800 \mathrm{ng} / \mathrm{g}: \mathrm{LW}$ & 146 \\
\hline & & Lake trout & whole & 1993 & $2000-4100 \mathrm{ng} / \mathrm{g}: \mathrm{LW}$ & 146 \\
\hline & & Lake trout & whole & 1982 & $6900 \mathrm{ng} / \mathrm{g}: \mathrm{LW}$ & 146 \\
\hline & & Lake trout & whole & 1992 & $2600 \mathrm{ng} / \mathrm{g}: \mathrm{LW}$ & 146 \\
\hline & Lake Superior & Lake trout & whole & 1982 & $4900 \mathrm{ng} / \mathrm{g}: \mathrm{WW}$ & 77 \\
\hline & & Lake trout & whole & 1982 & $28000 \mathrm{ng} / \mathrm{g}: \mathrm{LW}$ & 77 \\
\hline & & Lake trout & whole & $1992-94$ & $6700 \mathrm{ng} / \mathrm{g}: \mathrm{WW}$ & 77 \\
\hline & & Lake trout & whole & $1992-94$ & $35000 \mathrm{ng} / \mathrm{g}: \mathrm{LW}$ & 77 \\
\hline & & Rainbow smelt & whole & 1982 & $410 \mathrm{ng} / \mathrm{g}: \mathrm{WW}$ & 77 \\
\hline & & Rainbow smelt & whole & 1982 & $10000 \mathrm{ng} / \mathrm{g}: \mathrm{LW}$ & 77 \\
\hline & & Rainbow smelt & whole & $1992-94$ & $160 \mathrm{ng} / \mathrm{g}: \mathrm{WW}$ & 77 \\
\hline & & Rainbow smelt & whole & $1992-94$ & $3100 \mathrm{ng} / \mathrm{g}: \mathrm{LW}$ & 77 \\
\hline & & Bloater & muscle & 1994 & $840-1360 \mathrm{ng} / \mathrm{g}: \mathrm{WW}$ & 101 \\
\hline & & Smelt & muscle & 1994 & $99-210 \mathrm{ng} / \mathrm{g}: \mathrm{WW}$ & 101 \\
\hline & & Herring & muscle & 1994 & $560-720 \mathrm{ng} / \mathrm{g}: \mathrm{WW}$ & 101 \\
\hline & & Lake trout & muscle & 1994 & $250-540 \mathrm{ng} / \mathrm{g}: \mathrm{WW}$ & 101 \\
\hline & & Lake trout & whole & $1980 ?$ & 1926 ng/g : WW & 144 \\
\hline & & Herring & whole & $1980 ?$ & $1024 \mathrm{ng} / \mathrm{g}: \mathrm{WW}$ & 144 \\
\hline & & Sculpin & whole & $1980 ?$ & $546 \mathrm{ng} / \mathrm{g}: \mathrm{WW}$ & 144 \\
\hline & & Smelt & whole & $1980 ?$ & $291 \mathrm{ng} / \mathrm{g}: \mathrm{WW}$ & 144 \\
\hline & & Sculpin & whole & 1993 & $225 \mathrm{ng} / \mathrm{g}: \mathrm{DW}$ & 99 \\
\hline & & Sculpin & whole & 1994 & $260-460 \mathrm{ng} / \mathrm{g}: \mathrm{WW}$ & 101 \\
\hline
\end{tabular}


Table 3 continued

\begin{tabular}{|c|c|c|c|c|c|c|}
\hline Group & Location & Species & Tissue & Year & Concentration & Reference \\
\hline \multirow[t]{52}{*}{ Fish } & \multirow[t]{6}{*}{ Lake Superior } & Lake trout & whole & 1993 & $2373 \mathrm{ng} / \mathrm{g}: \mathrm{DW}$ & 99 \\
\hline & & Lake trout & whole & 1977 & $7200 \mathrm{ng} / \mathrm{g}: \mathrm{LW}$ & 146 \\
\hline & & Lake trout & whole & 1982 & $7000 \mathrm{ng} / \mathrm{g}: \mathrm{LW}$ & 146 \\
\hline & & Lake trout & whole & 1984 & $9700 \mathrm{ng} / \mathrm{g}: \mathrm{LW}$ & 146 \\
\hline & & Lake trout & whole & 1988 & $5500 \mathrm{ng} / \mathrm{g}: \mathrm{LW}$ & 146 \\
\hline & & Lake trout & whole & 1992 & $6400-6800 \mathrm{ng} / \mathrm{g}: \mathrm{LW}$ & 146 \\
\hline & \multirow[t]{10}{*}{ Lake Huron } & Lake trout & whole & $1980 ?$ & $365 \mathrm{ng} / \mathrm{g}: \mathrm{WW}$ & 144 \\
\hline & & Sculpin & whole & $1980 ?$ & $312 \mathrm{ng} / \mathrm{g}: \mathrm{WW}$ & 144 \\
\hline & & Smelt & whole & $1980 ?$ & $119 \mathrm{ng} / \mathrm{g}: \mathrm{WW}$ & 144 \\
\hline & & Alewife & whole & $1980 ?$ & $139 \mathrm{ng} / \mathrm{g}: \mathrm{WW}$ & 144 \\
\hline & & Lake trout & whole & 1982 & $4800 \mathrm{ng} / \mathrm{g}: \mathrm{LW}$ & 146 \\
\hline & & Lake trout & whole & 1992 & $1900 \mathrm{ng} / \mathrm{g}: \mathrm{LW}$ & 146 \\
\hline & & Lake trout & whole & 1982 & $5200 \mathrm{ng} / \mathrm{g}: \mathrm{WW}$ & 77 \\
\hline & & Lake trout & whole & 1982 & $30000 \mathrm{ng} / \mathrm{g}: \mathrm{LW}$ & 77 \\
\hline & & Lake trout & whole & $1992-94$ & $2400 \mathrm{ng} / \mathrm{g}: \mathrm{WW}$ & 77 \\
\hline & & Lake trout & whole & $1992-94$ & $13000 \mathrm{ng} / \mathrm{g}: \mathrm{LW}$ & 77 \\
\hline & \multirow{7}{*}{ Lake Erie } & Lake trout & whole & $1980 ?$ & $81 \mathrm{ng} / \mathrm{g}: \mathrm{WW}$ & 144 \\
\hline & & Smelt & whole & $1980 ?$ & $16 \mathrm{ng} / \mathrm{g}: \mathrm{WW}$ & 144 \\
\hline & & Alewife & whole & $1980 ?$ & $139 \mathrm{ng} / \mathrm{g}: \mathrm{WW}$ & 144 \\
\hline & & Walleye & whole & 1982 & $250 \mathrm{ng} / \mathrm{g}: \mathrm{WW}$ & 77 \\
\hline & & Walleye & whole & 1982 & $2200 \mathrm{ng} / \mathrm{g}: \mathrm{LW}$ & 77 \\
\hline & & Walleye & whole & $1992-94$ & $130 \mathrm{ng} / \mathrm{g}: \mathrm{WW}$ & 77 \\
\hline & & Walleye & whole & $1992-94$ & $1400 \mathrm{ng} / \mathrm{g}: \mathrm{LW}$ & 77 \\
\hline & \multirow[t]{14}{*}{ Lake Ontario } & Lake trout & whole & $1980 ?$ & $639 \mathrm{ng} / \mathrm{g}: \mathrm{WW}$ & 144 \\
\hline & & Sculpin & whole & $1980 ?$ & $245 \mathrm{ng} / \mathrm{g}: \mathrm{WW}$ & 144 \\
\hline & & Smelt & whole & $1980 ?$ & $66 \mathrm{ng} / \mathrm{g}: \mathrm{WW}$ & 144 \\
\hline & & Alewife & whole & $1980 ?$ & $49 \mathrm{ng} / \mathrm{g}: \mathrm{WW}$ & 144 \\
\hline & & Lake trout & whole & 1982 & $3600 \mathrm{ng} / \mathrm{g}: \mathrm{LW}$ & 146 \\
\hline & & Lake trout & whole & 1992 & $730 \mathrm{ng} / \mathrm{g}: \mathrm{LW}$ & 146 \\
\hline & & Lake trout & whole & 1982 & $4500 \mathrm{ng} / \mathrm{g}: \mathrm{WW}$ & 77 \\
\hline & & Lake trout & whole & 1982 & $24000 \mathrm{ng} / \mathrm{g}: \mathrm{LW}$ & 77 \\
\hline & & Lake trout & whole & $1992-94$ & $540 \mathrm{ng} / \mathrm{g}: \mathrm{WW}$ & 77 \\
\hline & & Lake trout & whole & $1992-94$ & $2800 \mathrm{ng} / \mathrm{g}: \mathrm{LW}$ & 77 \\
\hline & & Rainbow smelt & whole & 1982 & $720 \mathrm{ng} / \mathrm{g}: \mathrm{WW}$ & 77 \\
\hline & & Rainbow smelt & whole & 1982 & $11000 \mathrm{ng} / \mathrm{g}: \mathrm{LW}$ & 77 \\
\hline & & Rainbow smelt & whole & $1992-94$ & $67 \mathrm{ng} / \mathrm{g}: \mathrm{WW}$ & 77 \\
\hline & & Rainbow smelt & whole & $1992-94$ & $1100 \mathrm{ng} / \mathrm{g}: \mathrm{LW}$ & 77 \\
\hline & Lake Nipigon & Lake trout & whole & $1980 ?$ & $1009 \mathrm{ng} / \mathrm{g}: \mathrm{WW}$ & 144 \\
\hline & Lake Simcoe & Lake trout & whole & $1980 ?$ & $134 \mathrm{ng} / \mathrm{g}: \mathrm{WW}$ & 144 \\
\hline & Lake Opeongo & Lake trout & whole & $1980 ?$ & $89 \mathrm{ng} / \mathrm{g}: \mathrm{WW}$ & 144 \\
\hline & \multirow[t]{3}{*}{ Fumee Lake } & Smallmouth bass $(0-20 \mathrm{~cm})$ & whole & 1994 & $93-184 \mathrm{ng} / \mathrm{g}: \mathrm{WW}$ & 143 \\
\hline & & Smallmouth bass $(20-30 \mathrm{~cm}$ & whole & 1994 & $231-274 \mathrm{ng} / \mathrm{g}: \mathrm{WW}$ & 143 \\
\hline & & Smallmouth bass $(30<\mathrm{cm})$ & whole & 1994 & $246-367 \mathrm{ng} / \mathrm{g}: \mathrm{WW}$ & 143 \\
\hline & \multirow[t]{2}{*}{ Lake Carigellen } & Pike & spawn & 1979 & $30 \mathrm{ng} / \mathrm{g}: \mathrm{WW}$ & 26 \\
\hline & & Pike & spawn & 1979 & $240 \mathrm{ng} / \mathrm{g}: \mathrm{LW}$ & 26 \\
\hline & \multirow[t]{2}{*}{ Peanut Lake } & Rainbow trout & muscle & 1993 & $8 \mathrm{ng} / \mathrm{g}: \mathrm{WW}$ & 57 \\
\hline & & Rainbow trout & muscle & 1993 & $710 \mathrm{ng} / \mathrm{g}: \mathrm{LW}$ & 57 \\
\hline & \multirow[t]{2}{*}{ Chatwin Lake } & Rainbow trout & muscle & 1993 & $68 \mathrm{ng} / \mathrm{g}: \mathrm{WW}$ & 57 \\
\hline & & Rainbow trout & muscle & 1993 & 1040 ng/g : LW & 57 \\
\hline & \multirow[t]{3}{*}{ Slave River } & Walleye & whole & 1990 & $7-137 \mathrm{ng} / \mathrm{g}: \mathrm{WW}$ & 148 \\
\hline & & Walleye & whole & 1991 & $1-19 \mathrm{ng} / \mathrm{g}: \mathrm{WW}$ & 148 \\
\hline & & Burbot & liver & 1989 & $44-189 \mathrm{ng} / \mathrm{g}: \mathrm{WW}$ & 148 \\
\hline
\end{tabular}


Table 3 continued

\begin{tabular}{|c|c|c|c|c|c|c|}
\hline Group & Location & Species & Tissue & Year & Concentration & Reference \\
\hline \multirow[t]{11}{*}{ Fish } & \multirow[t]{4}{*}{ Slave River } & Burbot & liver & 1991 & $90-1057 \mathrm{ng} / \mathrm{g}: \mathrm{WW}$ & 148 \\
\hline & & Burbot & liver & $1991-92$ & $137-1887 \mathrm{ng} / \mathrm{g}: \mathrm{WW}$ & 148 \\
\hline & & Burbot & liver & $1992-93$ & $61-374 \mathrm{ng} / \mathrm{g}: \mathrm{WW}$ & 148 \\
\hline & & Burbot & liver & $1993-94$ & $283-703 \mathrm{ng} / \mathrm{g}: \mathrm{WW}$ & 148 \\
\hline & \multirow[t]{2}{*}{ Leland Lake } & Walleye & whole & 1990 & $0.6-90 \mathrm{ng} / \mathrm{g}: \mathrm{WW}$ & 148 \\
\hline & & Walleye & whole & 1991 & $1-14 \mathrm{ng} / \mathrm{g}: \mathrm{WW}$ & 148 \\
\hline & \multirow[t]{5}{*}{ Alexie Lake } & Burbot & liver & 1991 & $15-112 \mathrm{ng} / \mathrm{g}: \mathrm{WW}$ & 148 \\
\hline & & Burbot & liver & $1991-92$ & $34-91 \mathrm{ng} / \mathrm{g}: \mathrm{WW}$ & 148 \\
\hline & & Burbot & liver & $1992-93$ & $26-49 \mathrm{ng} / \mathrm{g}: \mathrm{WW}$ & 148 \\
\hline & & Burbot & liver & $1993-94$ & $34-91 \mathrm{ng} / \mathrm{g}: \mathrm{WW}$ & 148 \\
\hline & & Arctic char & muscle & $1994-95$ & $13 \mathrm{ng} / \mathrm{g}: \mathrm{WW}$ & 149 \\
\hline \multirow[t]{2}{*}{ Reptile } & \multirow[t]{2}{*}{ Mississippi } & Cottonmouth & whole & $1987-88$ & 1300 ng/g (Max.) : WW & 36 \\
\hline & & Water snake & whole & $1987-88$ & $27000 \mathrm{ng} / \mathrm{g}$ (Max.) : WW & 36 \\
\hline \multirow[t]{28}{*}{ Invertebrate } & Bering Sea & Crustacean & whole & 1988 & $1-2 \mathrm{ng} / \mathrm{g}: \mathrm{WW}$ & 35 \\
\hline & \multirow[t]{4}{*}{ Canadian Arctic } & Zooplankton & whole & 1986 & $24 \mathrm{ng} / \mathrm{g}: \mathrm{LW}$ & 59 \\
\hline & & Zooplankton & whole & 1987 & $160 \mathrm{ng} / \mathrm{g}: \mathrm{LW}$ & 59 \\
\hline & & Benthic amphipod & whole & 1986 & $1500 \mathrm{ng} / \mathrm{g}: \mathrm{LW}$ & 59 \\
\hline & & Benthic amphipod & whole & 1987 & $8300 \mathrm{ng} / \mathrm{g}: \mathrm{LW}$ & 59 \\
\hline & Arctic Ocean & Amphipod & whole & $1986-89$ & $16500 \mathrm{ng} / \mathrm{g}$ (Max.) : LW & 37 \\
\hline & Georges Bank & Scallop & muscle & 1979 & ND & 60 \\
\hline & Greenland & Blue mussel & muscle & $1994-95$ & ND & 61 \\
\hline & North Pacific Ocean & Blue mussel & muscle & $97-2001$ & $11 \mathrm{ng} / \mathrm{g}: \mathrm{LW}$ & 154 \\
\hline & \multirow[t]{5}{*}{ Lake Michigan } & Phytoplankton & whole & $1994-95$ & $51.3 \mathrm{ng} / \mathrm{g}: \mathrm{DW}$ & 99 \\
\hline & & Zooplankton & whole & $1994-95$ & $243 \mathrm{ng} / \mathrm{g}: \mathrm{DW}$ & 99 \\
\hline & & Mysis & whole & $1994-95$ & $92.4 \mathrm{ng} / \mathrm{g}: \mathrm{DW}$ & 99 \\
\hline & & Diporeia & whole & $1994-95$ & $411 \mathrm{ng} / \mathrm{g}: \mathrm{DW}$ & 99 \\
\hline & & Bythotrephes & whole & $1994-95$ & $162 \mathrm{ng} / \mathrm{g}: \mathrm{DW}$ & 99 \\
\hline & \multirow[t]{6}{*}{ Lake Superior } & Diporeia & whole & $1980 ?$ & $197 \mathrm{ng} / \mathrm{g}: \mathrm{WW}$ & 144 \\
\hline & & Mysis & whole & $1980 ?$ & $91 \mathrm{ng} / \mathrm{g}: \mathrm{WW}$ & 144 \\
\hline & & Mysis & whole & 1994 & $\mathrm{ND}-<50 \mathrm{ng} / \mathrm{g}: \mathrm{WW}$ & 101 \\
\hline & & Amphipod & whole & 1994 & $100 \mathrm{ng} / \mathrm{g}: \mathrm{WW}$ & 101 \\
\hline & & Limnocalanus & whole & 1994 & $\mathrm{ND}-180 \mathrm{ng} / \mathrm{g}: \mathrm{WW}$ & 101 \\
\hline & & Plankton & whole & $1980 ?$ & $62 \mathrm{ng} / \mathrm{g}: \mathrm{WW}$ & 144 \\
\hline & \multirow[t]{3}{*}{ Lake Huron } & Diporeia & whole & $1980 ?$ & $131 \mathrm{ng} / \mathrm{g}: \mathrm{WW}$ & 144 \\
\hline & & Mysis & whole & $1980 ?$ & $20 \mathrm{ng} / \mathrm{g}: \mathrm{WW}$ & 144 \\
\hline & & Plankton & whole & $1980 ?$ & $15 \mathrm{ng} / \mathrm{g}: \mathrm{WW}$ & 144 \\
\hline & \multirow[t]{2}{*}{ Lake Erie } & Diporeia & whole & $1980 ?$ & $29 \mathrm{ng} / \mathrm{g}: \mathrm{WW}$ & 144 \\
\hline & & Plankton & whole & $1980 ?$ & $<15 \mathrm{ng} / \mathrm{g}: \mathrm{WW}$ & 144 \\
\hline & \multirow[t]{3}{*}{ Lake Ontario } & Diporeia & whole & $1980 ?$ & $90 \mathrm{ng} / \mathrm{g}: \mathrm{WW}$ & 144 \\
\hline & & Mysis & whole & $1980 ?$ & $34 \mathrm{ng} / \mathrm{g}: \mathrm{WW}$ & 144 \\
\hline & & Plankton & whole & $1980 ?$ & $21 \mathrm{ng} / \mathrm{g}: \mathrm{WW}$ & 144 \\
\hline \multirow[t]{11}{*}{ Mammal } & \multirow[t]{3}{*}{ Arctic Ocean } & Beluga & blubber & $1986-89$ & $1400-8100 \mathrm{ng} / \mathrm{g}: \mathrm{WW}$ & 37 \\
\hline & & Narwhal & blubber & $1986-89$ & $2400-9200 \mathrm{ng} / \mathrm{g}: \mathrm{WW}$ & 37 \\
\hline & & Ringed seal & blubber & $1986-89$ & $480 \mathrm{ng} / \mathrm{g}$ (Max.) : WW & 37 \\
\hline & \multirow[t]{2}{*}{ Baltic Sea } & Grey seal & blubber & $1974-77$ & $11000 \mathrm{ng} / \mathrm{g}: \mathrm{LW}$ & 71 \\
\hline & & Harbor seal & blubber & 1988 & $1500 \mathrm{ng} / \mathrm{g}: \mathrm{LW}$ & 43 \\
\hline & Lake Baikal & Baikal seal & blubber & 1991 & $2200-2300 \mathrm{ng} / \mathrm{g}: \mathrm{LW}$ & 27 \\
\hline & \multirow[t]{2}{*}{ North Sea } & White-beaked dolphin & blubber & & $19000 \mathrm{ng} / \mathrm{g}: \mathrm{WW}$ & 58 \\
\hline & & Harbor porpoise & blubber & 1990 & $6800 \mathrm{ng} / \mathrm{g}: \mathrm{WW}$ & 30 \\
\hline & Mississippi & Ruccoon & blubber & 1988 & $20 \mathrm{ng} / \mathrm{g}: \mathrm{WW}$ & 41 \\
\hline & \multirow[t]{2}{*}{ Beaufort Sea } & Beluga (m) & blubber & $1983-87$ & $3830 \mathrm{ng} / \mathrm{g}: \mathrm{WW}$ & 67 \\
\hline & & Beluga (f) & blubber & $1983-87$ & $1380 \mathrm{ng} / \mathrm{g}: \mathrm{WW}$ & 67 \\
\hline
\end{tabular}


Table 3 continued

\begin{tabular}{|c|c|c|c|c|c|c|}
\hline Group & Location & Species & Tissue & Year & Concentration & Reference \\
\hline \multirow[t]{28}{*}{ Mammal } & Jones Sound & Beluga (m) & blubber & 1984 & $4250 \mathrm{ng} / \mathrm{g}: \mathrm{WW}$ & 67 \\
\hline & & Beluga (f) & blubber & 1984 & $3740 \mathrm{ng} / \mathrm{g}: \mathrm{WW}$ & 67 \\
\hline & Hudson Bay & Beluga (m) & blubber & 1986 & $5100 \mathrm{ng} / \mathrm{g}: \mathrm{WW}$ & 67 \\
\hline & & Beluga (f) & blubber & 1986 & $1770 \mathrm{ng} / \mathrm{g}: \mathrm{WW}$ & 67 \\
\hline & Cumberland Sound & Beluga (m) & blubber & 1983 & $5780 \mathrm{ng} / \mathrm{g}: \mathrm{WW}$ & 67 \\
\hline & & Beluga (f) & blubber & 1983 & $1770 \mathrm{ng} / \mathrm{g}: \mathrm{WW}$ & 67 \\
\hline & St. Lawrence River & Beluga (m) & blubber & $1987-90$ & $2410-45600 \mathrm{ng} / \mathrm{g}: \mathrm{WW}$ & 147 \\
\hline & & Beluga (f) & blubber & $1987-90$ & $2271-3240 \mathrm{ng} / \mathrm{g}: \mathrm{WW}$ & 147 \\
\hline & Baffin bay & Narwhal (m) & blubber & $1982-83$ & $9160 \mathrm{ng} / \mathrm{g}: \mathrm{WW}$ & 68 \\
\hline & & Narwhal (f) & blubber & $1982-83$ & $2440 \mathrm{ng} / \mathrm{g}: \mathrm{WW}$ & 68 \\
\hline & Baffin Island & Narwhal & blubber & 1995 & $18070 \mathrm{ng} / \mathrm{g}: \mathrm{WW}$ & 138 \\
\hline & Alaska & Beluga (Fetus) & blubber & 1992 & $3710 \mathrm{ng} / \mathrm{g}: \mathrm{LW}$ & 69 \\
\hline & & Beluga (Mother) & blubber & 1992 & $3200 \mathrm{ng} / \mathrm{g}: \mathrm{LW}$ & 69 \\
\hline & & Beluga (f) & blubber & 1992 & $2380-3540 \mathrm{ng} / \mathrm{g}: \mathrm{LW}$ & 69 \\
\hline & & Beluga (m) & blubber & 1992 & $4060-15940 \mathrm{ng} / \mathrm{g}: \mathrm{LW}$ & 69 \\
\hline & Bering Sea & Walrus & blubber & $1981-84$ & $<100 \mathrm{ng} / \mathrm{g}: \mathrm{WW}$ & 70 \\
\hline & Skagerrak & Harbor seal & blubber & 1988 & $350 \mathrm{ng} / \mathrm{g}: \mathrm{LW}$ & 43 \\
\hline & Greenland & Ringed seal & blubber & $1994-95$ & $260 \mathrm{ng} / \mathrm{g}: \mathrm{WW}$ & 61 \\
\hline & Caspian Sea & Seal (m) & blubber & 1993 & $8.3 \mathrm{ng} / \mathrm{g}: \mathrm{WW}$ & 64 \\
\hline & Newfoundland & Long-finned pilot whale (m) & blubber & $1980-82$ & $4300-14700 \mathrm{ng} / \mathrm{g}: \mathrm{WW}$ & 42 \\
\hline & & Long-finned pilot whale (f) & blubber & $1980-82$ & $500-11800 \mathrm{ng} / \mathrm{g}: \mathrm{WW}$ & 42 \\
\hline & & White-beaked dolphin (m) & blubber & $1980-82$ & $13000-87000 \mathrm{ng} / \mathrm{g}: \mathrm{WW}$ & 42 \\
\hline & & White-beaked dolphin (f) & blubber & $1980-82$ & $9600-39700 \mathrm{ng} / \mathrm{g}: \mathrm{WW}$ & 42 \\
\hline & Sweden & Harbor seal (m) & blubber & 1988 & $400 \mathrm{ng} / \mathrm{g}: \mathrm{WW}$ & 43 \\
\hline & & Harbor seal (Juvenile) & blubber & 1988 & $300-1500 \mathrm{ng} / \mathrm{g}: \mathrm{WW}$ & 43 \\
\hline & & Grey seal (m) & blubber & 1988 & $1900 \mathrm{ng} / \mathrm{g}: \mathrm{WW}$ & 43 \\
\hline & & Grey seal (f) & blubber & 1988 & $3100-10000 \mathrm{ng} / \mathrm{g}: \mathrm{WW}$ & 43 \\
\hline & & Ringed seal & blubber & 1988 & $3100 \mathrm{ng} / \mathrm{g}: \mathrm{WW}$ & 43 \\
\hline \multirow[t]{6}{*}{ Human } & Sweden & & milk & $1978-79$ & $100 \mathrm{ng} / \mathrm{g}: \mathrm{LW}$ & 112 \\
\hline & Canada & & milk & 1992 & $6.03 \mathrm{ng} / \mathrm{g}: \mathrm{LW}$ & 113 \\
\hline & & & milk & 1986 & $12.1 \mathrm{ng} / \mathrm{g}: \mathrm{LW}$ & 113 \\
\hline & Nicaragua & & milk & $?$ & $34 \mathrm{ng} / \mathrm{g}: \mathrm{WW}$ & 58 \\
\hline & GL Basin & & milk & 1992 & $7.28 \mathrm{ng} / \mathrm{g}: \mathrm{LW}$ & 113 \\
\hline & Keewatin & & milk & 1997 & $67.7 \mathrm{ng} / \mathrm{g}: \mathrm{LW}$ & 113 \\
\hline
\end{tabular}

Table 4 Physicochemical property of toxaphene

\begin{tabular}{|c|c|c|c|c|c|c|}
\hline CAS No. & $\begin{array}{l}\text { Average } \\
\text { Empirical } \\
\text { formula }\end{array}$ & $\begin{array}{c}\text { Melting point } \\
\mathrm{K}\end{array}$ & $\begin{array}{c}\text { Water solubility }^{81)} \\
\mathrm{mg} / \mathrm{L}\end{array}$ & $\begin{array}{c}\text { Vapor pressure } \\
\mathrm{Pa} \times 10^{4}\end{array}$ & $\begin{array}{l}\text { Henry's constant }{ }^{83)} \\
\qquad \mathrm{Pa} \mathrm{m} / \mathrm{mol}\end{array}$ & $\begin{array}{c}\text { Octanol-water partition } \\
\text { coefficient }^{84)}\left(K_{\text {ow }}\right) \\
\log K_{\text {ow }}\end{array}$ \\
\hline $8001-35-2$ & $\mathrm{C}_{10} \mathrm{H}_{10} \mathrm{Cl}_{8}$ & $338-363$ & $0.4(298 K)$ & $8.92(293 \mathrm{~K})$ & $0.61(293 \mathrm{~K})$ & 5.5 \\
\hline
\end{tabular}

れた塩素化カンフェンは重量換算で $67 \%$ から $69 \%$ の塩素 を含有する゙”。ここで, Fig. 1 にトキサフェンの主要成分 であるボルナンの炭素骨格を示す。これによると塩素化 ボルナンの理論的な異性体の総数は, $\mathrm{C}_{10} \mathrm{H}_{18-\mathrm{x}} \mathrm{Cl}_{\mathrm{x}}(\mathrm{X}=$ 1-18）より 32,768 種 ${ }^{7)}$ と計算されるが，ボルナンは橋頭 構造であるため実際には4-位の炭素原子に塩素原子は
配位しないであろう。Hainzl らは, 工業用トキサフェン に 1 塩素化ボルナンと 2 塩素化ボルナンは存在しないこ とや, 立体障害を考慮すると光学異性体を含めた塩素化 ボルナンの異性体総数は 4,096 種 ${ }^{79}$ と推定した。そこで, トキサフェンの分析值の比較検討を容易に行うために, 規則的命名や主要異性体の通称が発案された。例えば, 


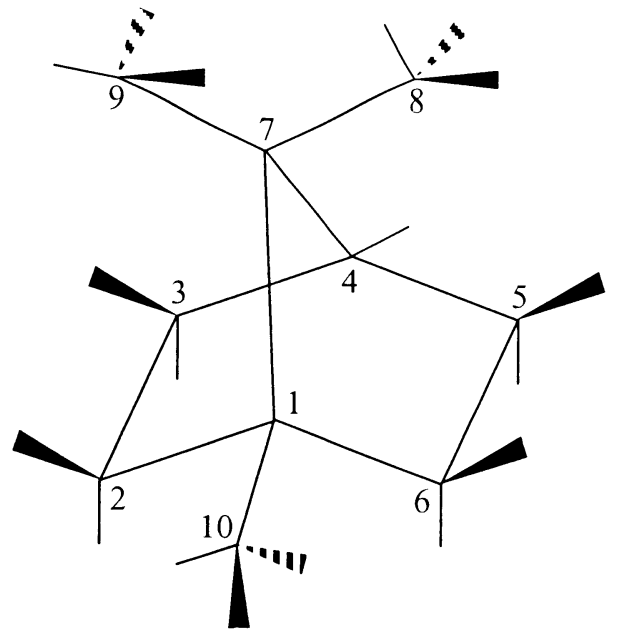

Fig. 1 Bornane skelton

Parlar らはトキサフェン混合物からの単離と同定（無極 性, または 5 \%フェニル-95\%ジメチルポリシロキサン 相当のカラムに対する溶出順序に対応）に基づき，17種 の塩素化ボルナンと 5 種の塩素化カンフェンについて Parlar Numbers ${ }^{85}$ を付与している。一方, Wester らの命 名法 ${ }^{87}$ は Fig. 1における「2-位炭素原子から6-位炭素原 子」と「8-位炭素原子から10-位炭素原子」を 2 つのグ ループに大別し, 各炭素原子に配位する塩素原子数の組 み合わせで命名を行っているため，その構造が容易に理 解できる利点がある。また Andrews と Vetter の命名法 $(\text { 以下, AV code })^{86)}$ も文献等で頻繁に見受けられる。 Table 5 にIUPAC 命名法とその通称をまとめる。なお, 本誌における説明では便宜上 AV code を採用した。

\section{3. 残留性}

世界保健機関（以下，WHO）の報告では，粘土質の土 壤に扔けるトキサフェンの半減期は含水条件で179日, 乾燥条件で705日である ${ }^{97}$ 。一方, Jensen は土壤中での半 減期として嫌気性条件で 6 週間, 好気性条件で 10 年 ${ }^{95}$ と 提示している。半減期は土性，土壤吸着平衡定数や $\log$ $K_{\mathrm{ow}}$ など諸条件の兼ね合いで得られるため，単純な比較 はできないかもしれないが，この值はDDT, Dieldrin, $\gamma-\mathrm{HCH}$ といった他の有機塩素化合物（以下，OCs）よ りも小さな值であり, OCs としては比較的分解されやす いことが示唆される。トキサフェンの分解は，紫外線や 太陽光を含めた光分解に加えて, 生物分解などを経由し て進行するものと推測されるが，いずれにしても最終的 には難分解性の残留物が生成するであろう。実際，嫌気 性条件下での検討 ${ }^{56)}$ では, 土潩中の塩素化ボルナンの主 要な反応過程として還元脱塩素化を経由して塩素原子が
逐次に脱離することが確認されており，その脱塩素化速 度は高塩素化ボルナンほど速く，結果的に 2 種の安定 な 6 塩素化ボルナン (2-exo, 5-endo, 6-exo, 8,9,10Hexachlorobornane および2-endo, 5-endo, 6-exo, 8, 9, 10Hexachlorobornane）へ変化したと報告されている。脱塩 素化速度に関するこのオーダーは，嫌気性下水スラッジ 中の工業用トキサフェンでも同様に確認98) されており, 特に 6 員環炭素において 2 つ塩素原子が同一の炭素原 子に置換した構造をもつ, いわゆる gem-塩素置換体が 最も迅速に分解された。また，その分解過程は還元脱塩 素化経由であり，難分解性生成物として B6-923や B71001 生成した。

その一方で，水中のトキサフェンは極めて安定との報 告がある。実際には $\mathrm{pH}$ や水温分布以外に鉛直分布, 層 密度, 滞留などの諸因子と流入や流出等の外部因子が相 互に影響すると思われるが，実験室内での検討では水温 $25^{\circ} \mathrm{C}, \mathrm{pH} 5 \sim 8$, 酸素含有量などの条件を設定するこ とで，トキサフェンは 5 年間以上残留した ${ }^{13)}$ との報告が あり，同様の知見は Jensen からも得られている ${ }^{95)}$ 。生物 相における残留性では, Fisk らが Rainbow trout中の B7-1001，B8-1413およびB9-1679の 3 種異性体を測定 し，その半減期をそれぞれ32日，43日，42 日 ${ }^{96}$ と見積っ た。このようにトキサフェンは存在する環境によってそ の分解速度や蓄積, 代謝挙動が異なることから, 各環境 媒体に特有な異性体が長期間残留するものと考えられ る。Miskimmin らは，30年前にトキサフェンを散布した 湖の堆積物コアとそこに棲息する Rainbow troutを調査 し 57)，異性体情報に基づいた污染源の解明を行ってい る。彼らは, 堆積物コア試料から高濃度の塩素化ボルナ ンを, 表層試料から 6 塩素化および 7 塩素化ボルナン を, Rainbow troutから堆積物コアと同様の塩素化ボル ナンのクロマトパターンを見出したことから, 環境中で 脱塩素化した生成物が環境中へ再分配することにより生 物濃縮を引き起こすものと推定した。これに関連して湖 の堆積物コアを調査した報告の中で, Pearsonらは, 五 大湖の污染源が基本的には大気由来であり, 堆積物コア 中でトキサフェンが非常に遅い速度で分解している ${ }^{102)}$ とを明らかにした。この堆積物中での分解は, Vetter ら

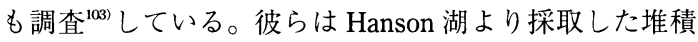
物コア中のトキサフェン残留物の組成を調査した結果, 主要な異性体はB6-923と B7-1001であることを究明し た。さらにこれら異性体は高塩素化体の代謝物であると して, 還元脱塩素化が Hanson 湖堆積物中の主要な微生 物分解経路であると結論付けている。

水や大気などの非生物相における最も主要な分解経路 は，光分解であることが Parlar らにより指摘 ${ }^{108}$ されてい る。Parlarらはトキサフェンの光分解について，6員環 炭素原子の2-位炭素原子，3-位炭素原子，5-位炭素原 
Table 5 IUPAC names and other common names of individual toxaphene congeners

\begin{tabular}{|c|c|c|c|c|}
\hline IUPAC names & $\begin{array}{l}\text { Parlar } \\
\text { et al. }\end{array}$ & $\begin{array}{c}\text { Andrews and } \\
\text { Vetter }^{86)}\end{array}$ & $\begin{array}{l}\text { Wester } \\
\text { et al. }^{87)}\end{array}$ & $\begin{array}{l}\text { Nikiforov } \\
\text { et al. }\end{array}$ \\
\hline 2-exo,3-endo,6-endo,8,9,10-hexachlorobornane & & B6-913 & $\mathrm{B}[21001]-(111)$ & $\mathrm{HxCB}-3156$ \\
\hline 2-exo,3-endo,6-exo,8,9,10-hexachlorobornane & & B6-923 & $\mathrm{B}[21002]-(111)$ & $\mathrm{HxCB}-3124$ \\
\hline $2,2,5,5,9,10,10$-heptachlorobornane & 21 & B7-499 & $\mathrm{B}[30030]-(012)$ & HpCB-6533 \\
\hline 2,2,5-endo,6-exo,8,9,10-heptachlorobornane & 32 & B7-515 & $\mathrm{B}[30012]-(111)$ & HpCB-6452 \\
\hline 2,2,5-exo,8,9,10,10-heptachlorobornane & & B7-560 & $\mathrm{B}[30020]-(112)$ & HpCB-6293 \\
\hline 2-endo,3-exo,5-endo,6-exo,8,9,10-heptachlorobornane & & B7-1001 & $\mathrm{B}[12012]-(111)$ & HрCB-4916 \\
\hline 2-endo,3-exo,5-exo,6-exo,8,10,10-heptachlorobornane & & B7-1026 & $\mathrm{B}[12022]-(102)$ & НpCB-4785 \\
\hline 2-endo,3-exo,6-exo,8,9,10,10-heptachlorobornane & & B7-1059 & $\mathrm{B}[12002]-(112)$ & $\mathrm{HpCB}-4661$ \\
\hline 2-exo,3-endo,5-exo,8,9,10,10-heptachlorobornane & & B7-1450 & $\mathrm{B}[21020]-(112)$ & HpCB-3221 \\
\hline 2-exo,3-endo,5-exo,9,9,10,10-heptachlorobornane & & B7-1453 & $\mathrm{B}[21020]-(022)$ & НpCB-3207 \\
\hline 2-exo,3-endo,6-endo, $8,9,10,10$-heptachlorobornane & & B7-1462 & $\mathrm{B}[21001]-(112)$ & HpCB-3157 \\
\hline 2-endo,3-endo,5-exo,6-exo,9,10,10-heptachlorobornane & & B7-1572 & $\mathrm{B}[11022]-(012)$ & HpCB-5285 \\
\hline 2-exo,3-exo,5-endo,8,9,10,10-heptachlorobornane & & B7-1584 & $\mathrm{B}[22010]-(112)$ & НpCB-2837 \\
\hline 2-endo,3-exo,5-exo,6-exo,9,10,10-heptachlorobornane & & B7-1592 & $\mathrm{B}[12022]-(012)$ & HрCB-4773 \\
\hline 2-exo,5,5,8,9,10,10-heptachlorobornane & & B7-1712 & $\mathrm{B}[20030]-(112)$ & НpCB-2453 \\
\hline 2-exo,5,5,9,9,10,10-heptachlorobornane & & B7-1715 & $\mathrm{B}[20030]-(022)$ & НрСВ-2439 \\
\hline 2,2,3-exo,5-endo,6-exo,8,9,10-octachlorobornane & 39 & B8-531 & $\mathrm{B}[32012]-(111)$ & OCB-6964 \\
\hline 2,2,5,5,6-endo $, 8,9,10$-octachlorobornane & & B8-763 & $\mathrm{B}[30031]-(111)$ & OCB-6612 \\
\hline $2,2,5,5,8,9,10,10$-octachlorobornane & 51 & B8-786 & $\mathrm{B}[30030]-(112)$ & OCB-6549 \\
\hline $2,2,5,5,9,9,10,10$-octachlorobornane & 38 & B8-789 & $\mathrm{B}[30030]-(022)$ & OCB-6535 \\
\hline 2,2,5-endo,6-exo,8,8,9,10-octachlorobornane & $42 a$ & B8-806 & $\mathrm{B}[30012]-(211)$ & OCB- 6460 \\
\hline 2,2,5-endo,6-exo,8,9,9,10-octachlorobornane & $42 b$ & B8-809 & $\mathrm{B}[30012]-(121)$ & OCB-6454 \\
\hline 2,2,5-endo,6-exo,8,9,10,10-octachlorobornane & & B8-810 & $\mathrm{B}[30012]-(112)$ & OCB-6453 \\
\hline 2-endo,3,3,5-exo,6-exo,9,10,10-octachlorobornane & & B8-1058 & $\mathrm{B}[13022]-(012)$ & OCB-5797 \\
\hline 2-endo ,3-endo,5-exo,6-exo,8,9,10,10-octachlorobornane & & B8-1252 & $\mathrm{B}[11022]-(112)$ & OCB-5301 \\
\hline 2-endo,3-exo,5-endo,6-exo,8,8,10,10-octachlorobornane & 26 & B8-1413 & $\mathrm{B}[12012]-(202)$ & OCB-4921 \\
\hline 2-endo,3-exo,5-endo,6-exo,8,9,10,10-octachlorobornane & 40 & B8-1414 & $\mathrm{B}[12012]-(112)$ & OCB -4917 \\
\hline 2-endo,3-exo,5-exo,6-exo,8,9,10,10-octachlorobornane & & B8-1440 & $\mathrm{B}[12022]-(112)$ & OCB-4789 \\
\hline 2-exo,3-endo,5-exo,8,9,9,10,10-octachlorobornane & 41 & B8-1945 & $\mathrm{B}[21020]-(122)$ & OCB-3223 \\
\hline 2-exo,3-exo,5,5,8,8,10,10-octachlorobornane & & B8-2075 & $\mathrm{B}[22030]-(202)$ & OCB-2969 \\
\hline 2-exo,3-exo,5,5,8,9,10,10-octachlorobornane & & B8-2078 & $\mathrm{B}[22030]-(112)$ & OCB-2965 \\
\hline 2-exo,5,5,8,9,9,10,10-octachlorobornane & 44 & B8-2229 & $\mathrm{B}[20030]-(122)$ & OCB-2455 \\
\hline 2,2,3-exo,5,5,8,9,10,10-nonachlorobornane & 58 & B9-715 & $\mathrm{B}[32030]-(112)$ & NCB-7061 \\
\hline 2,2,3-exo,5,5,9,9,10,10-nonachlorobornane & & B9-718 & $\mathrm{B}[32030]-(022)$ & NCB-7047 \\
\hline 2,2,3-exo,5-endo,6-exo,8,9,9,10-nonachlorobornane & & B9-742 & $\mathrm{B}[32012]-(121)$ & NCB-6966 \\
\hline 2,2,3-exo,5-endo,6-exo,8,9,10,10-nonachlorobomane & & B9-743 & $\mathrm{B}[32012]-(112)$ & NCB-6965 \\
\hline 2,2,5,5,6-exo $, 8,9,9,10$-nonachlorobornane & & B9-1011 & $\mathrm{B}[30032]-(121)$ & NCB-6582 \\
\hline $2,2,5,5,8,9,9,10,10$-nonachlorobornane & 62 & B9-1025 & $\mathrm{B}[30030]-(122)$ & NCB-6551 \\
\hline 2,2,5-endo,6-exo,8,8,9,10,10-octachlorobornane & 56 & B9-1046 & $\mathrm{B}[30012]-(212)$ & NCB-6461 \\
\hline 2,2,5-endo,6-exo,8,9,9,10,10-octachlorobornane & 59 & B9-1049 & $\mathrm{B}[30012]-(122)$ & NCB-6455 \\
\hline 2-exo,3,3,5-exo,6-endo, $8,9,10,10$-nonachlorobornane & & B9-2006 & $\mathrm{B}[13022]-(112)$ & NCB-5813 \\
\hline 2-endo,3-exo,5-endo,6-exo,8,8,9,10,10-nonachlorobornane & 50 & B9-1679 & $\mathrm{B}[12012]-(212)$ & NCB-4925 \\
\hline 2-endo,3-exo,5-endo,6-exo, $8,9,9,10,10$-nonachlorobornane & & B9-2200 & $\mathrm{B}[12012]-(122)$ & NCB-4919 \\
\hline 2-exo,3-endo,5-exo,6-exo,8,8,9,10,10-nonachlorobornane & 63 & B9-2206 & $\mathrm{B}[21022]-(212)$ & NCB-3261 \\
\hline 2,2,3-exo,5,5,8,9,9,10,10-decachlorobornane & & B10-831 & $\mathrm{B}[32030]-(122)$ & DCB-7063 \\
\hline 2,2,3-exo,5-endo,6-exo,8,9,9,10,10-decachlorobornane & & B10-860 & $\mathrm{B}[32012]-(122)$ & DCB-6967 \\
\hline 2,2,5,5,6-exo,8,9,9,10,10-decachlorobornane & 69 & B10-1110 & $\mathrm{B}[30032]-(122)$ & DCB-6583 \\
\hline 2-endo ,3,3,5-endo,6-endo ,8,9,9,10,10-decachlorobornane & & B10-1361 & $\mathrm{B}[13011]-(122)$ & DCB-5975 \\
\hline 2-exo,3,3,5-exo,6-endo,8,9,9,10,10-decachlorobornane & & B10-1993 & $\mathrm{B}[23021]-(122)$ & DCB-3799 \\
\hline 2,5-endo,6-exo,8,9,10-hexachloroborn-2-ene & & & $E[10012]-(111)$ & \\
\hline
\end{tabular}


Table 5 continued

\begin{tabular}{|c|c|c|c|c|}
\hline IUPAC names & $\begin{array}{l}\text { Parlar } \\
\text { et al. }^{85)}\end{array}$ & $\begin{array}{c}\text { Andrews and } \\
\text { Vetter }^{86)}\end{array}$ & $\begin{array}{l}\text { Wester } \\
\text { et al. }^{87)}\end{array}$ & $\begin{array}{c}\text { Nikiforov } \\
\text { et al. }^{88)}\end{array}$ \\
\hline 3,6,6,8,9,10-hexachloroborn-2-ene & & & $E[01003]-(111)$ & \\
\hline 3,5-exo, $6,6,8,9,10$-heptachloroborn-2-ene & & & $\mathrm{E}[01023]-(111)$ & \\
\hline 2,3,5-exo,6-exo,9,10,10-heptachloroborn-2-ene & & & $\mathrm{E}[11022]-(012)$ & \\
\hline 2,3,5-exo,6-exo,8,9,10,10-octachloroborn-2-ene & & & $\mathrm{E}[11022]-(112)$ & \\
\hline 2,5-endo,6-exo,8,9,9,10,10-octachloroborn-2-ene & & & $\mathrm{E}[10012]-(122)$ & \\
\hline $2,3,5,8,9,10$-hexachloroborn-2,5-diene & & & $\mathrm{D}[11010]-(111)$ & \\
\hline 2,2,3-exo,8,9,10-hexachlorocamphene & 11 & & $C[032001]-(11)$ & \\
\hline 2-exo,3-endo,8,8,9,10-hexachlorocamphene & 12 & & $\mathrm{C}[021001]-(21)$ & \\
\hline 2-exo,3-endo,7,8,9,10-hexachlorocamphene & 15 & & $C[021011]-(11)$ & \\
\hline 2,2,3-exo,8,8,9,10-heptachlorocamphene & 25 & & $C[032001]-(21)$ & \\
\hline 2,2,3-exo,8,8,9,9,10-octachlorocamphene & 31 & & $C[032001]-(22)$ & \\
\hline 2-exo,3-exo,6-exo,8,9,10,10-heptachlorodihydrocamphene & & & $\mathrm{DC}[022020]-(112)$ & \\
\hline
\end{tabular}

子，6-位炭素原子にそれぞれ 1 個の塩素原子を配位し， なお且つ, 各塩素原子の配向性が交互の向きになってい る塩素化ボルナンが光に対して極めて安定であると述べ ている ${ }^{108)}$ 。具体的には, 2-endo, 3-exo, 5-endo, 6-exo に塩素原子が配位したボルナンを指摘していることか ら, Parlar Numbersを持つ塩素化ボルナンの中では, B8-1413，B8-1414および B9-1679がこれに該当する。 さらにParlarは, gem-塩素を持つ異性体が光に対してよ り反応活性であり，特に2-位炭素原子にジクロロ基が 配位している場合にはその傾向が顕著に表れる(108) として いる。分子モデルより誘導した熱力学データからも類似 した考察 ${ }^{109}$ が得られており，塩素原子が配位した際に立 体障害がなく 6 員環にも歪を生じないような異性体が最 も安定，すなわち残留性が高いと結論付けられる。

以上のことから, 環境中に残留するトキサフェンは生 物的または非生物的分解過程により組成変化を起こして いることがわかる。特に脂質中の残留物などでは経年変 化を通じての組成変化が顕著に見受けられ, 本来の工業 用トキサフェンとは異なるクロマトパターンを示す ${ }^{2,31}$ ことが指摘されている。トキサフェンの移動および拡散 は, 主に大気や水を介する年文と考えられているが, この 場合にも組成変化は起こり得る。よって, 異性体の組成 情報から污染源を推定する試みは他の OCsよりも困難 であると推測される。

\section{4. 代謝}

トキサフェンの $K_{\mathrm{ow}}$ は 100,000 以上あることから，生 物濃縮が強く懸念される。しかしながら, 水生生物に取 り达まれたOCs は体外へ排泄される傾向があるため，体 内への蓄積は低いものと考えられる。例として, Table $6^{105)}$ に魚類に対する生物濃縮係数（以下, BCFs）を示
す。Table 6 の BCFs は実測値の $\log K_{\mathrm{ow}}$ からの計算值で あるが, これらの值を各種魚類で測定した生物蓄積係数 (以下, BAFs) と比較した場合, BAFs は BCFs の最大 70倍と見積られた。Swackhamerらも，Phytoplankton, Zooplankton, Mysis, Bythotrephes, Sculpin, Lake trout について $\mathrm{BAFs}^{99)}$ を求めており, トキサフェンが食物 連鎖中で生物濃縮することを明らかにした。水生生物に 対して高い残留性を示す特徽的異性体としては, B81413, B8-1414, B8-1945, B8-2229, B9-1679, B91025の 6 種異性体が挙げられる。Kimmelらは,これら 6 成分が魚油中のトキサフェンの 80 ～85\%を占める ${ }^{106)}$ 報告しており，魚および魚油の残留分析の標準法として これら異性体の使用を薦めている。その一方でChan ら の調査によれば，カナダの Yukon 州で採取した魚類を用 いて B8-1413, B9-1679, B9-1025の3 成分を定量した ところ, トキサフェン濃度に占める 3 成分の割合は魚種

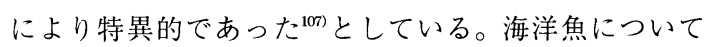
は, 含有するトキサフェン濃度が魚齢と正の相関にある との知見 ${ }^{144,115)}$ も報告されている。海洋哺乳類の代謝に関 する検討としては Vetter らの報告が挙げられる。Vetter らは 3 種の Seal の脳組織と脂肪に含有される特徵的異 性体をキラル固定相により分離し, そのエナンチオマ比

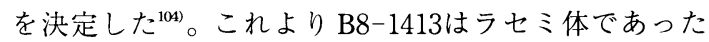
が, B8-1412, B8-2229および B9-1025は複数の高次栄 養水準生物相中でエナンチオマ的に濃縮されることが確 認された。このエナンチオマ的な濃縮は, 以前に報告さ れた Codfish の肝油と魚油試料を用いた Angerhöfer らの 検討 ${ }^{111)}$ においても指摘されている。B8-2229および B91025はVetter らの報告と同様にエナンチオマ的な濃縮が 認められ, さらにB9-1679はラセミ体であることが見出 された。海洋哺乳類の代謝ではアッセイ系を利用した調 
査も行われている。この調査 ${ }^{110)}$ は海洋哺乳類と鳥類の工 業用トキサフェンに対する代謝能を肝ミクロソームの in vitro アッセイを利用して測定している。その結果, 代 謝能のオーダーは Harbour seal > White-beaked dolphin $\fallingdotseq$ Laysan albatross $>$ Sperm whale であり, Harbour seal のミクロソームはB7-515と B9-1025は代謝するが, B81413と B9-1679は代謝しないことが示唆された。さらに 母乳に関する調査も行われている。カナダの Newsome らは，母乳中で高い割合を占める異性体として B8-1413 と B9-1679を挙げている ${ }^{113)}$ 。1986年から1997年の間で延 べ100人分の母乳を分析した結果, 両異性体の占める割 合は 47 ～86\%の範囲であった。

トキサフェンの母子移行を検討した研究 ${ }^{69)}$ は Wade ら

Table 6 BCFs of polychlorinated bornane congeners in aquatic organisms

\begin{tabular}{|c|c|c|c|}
\hline Congeners & $\begin{array}{l}\log B C F \\
\text { wet basis }\end{array}$ & $\begin{array}{l}\log B C F \\
\text { lipid basis }\end{array}$ & $\log K_{\text {ow }}{ }^{145)}$ \\
\hline \multirow{2}{*}{ B7-1457 } & $4.50^{\mathrm{a})}$ & $5.80^{\mathrm{a})}$ & 5.80 \\
\hline & $4.63^{\mathrm{a})}$ & $5.93^{\text {a) }}$ & 5.93 \\
\hline \multirow{6}{*}{ B8-1413 } & $4.68^{\mathrm{a})}$ & $6.00^{\mathrm{a})}$ & \\
\hline & $4.81^{\text {a) }}$ & $6.11^{\text {a) }}$ & \\
\hline & $5.21^{\mathrm{b})}$ & $7.04^{b)}$ & 5.98 \\
\hline & $5.12^{\mathrm{c})}$ & $7.14^{c)}$ & 6.11 \\
\hline & $5.90^{\mathrm{d})}$ & $7.48^{\mathrm{d})}$ & \\
\hline & $6.75^{\mathrm{e})}$ & $7.83^{e)}$ & \\
\hline \multirow{2}{*}{ B8-1414 } & $4.75^{\mathrm{a})}$ & $6.04^{a)}$ & 6.05 \\
\hline & $4.88^{\text {a) }}$ & $6.18^{\mathrm{a})}$ & 6.18 \\
\hline \multirow{2}{*}{ B8-1945 } & $4.75^{\mathrm{a})}$ & $6.05^{\mathrm{a})}$ & 6.05 \\
\hline & $4.88^{a)}$ & $6.18^{\mathrm{a})}$ & 6.18 \\
\hline \multirow{2}{*}{ B8-2229 } & $5.49^{\text {a) }}$ & $6.79^{\text {a) }}$ & 6.79 \\
\hline & $5.62^{\mathrm{a})}$ & $6.92^{\mathrm{a})}$ & 6.92 \\
\hline \multirow{6}{*}{ B9-1679 } & $4.93^{\mathrm{a})}$ & $6.23^{\mathrm{a})}$ & \\
\hline & $5.06^{\mathrm{a})}$ & $6.36^{\mathrm{a})}$ & \\
\hline & $5.46^{\mathrm{b})}$ & $7.30^{b)}$ & 6.23 \\
\hline & $5.00^{\mathrm{c})}$ & $7.00^{c)}$ & 6.36 \\
\hline & $5.83^{\mathrm{d})}$ & $7.40^{d)}$ & \\
\hline & $5.81^{e)}$ & $7.89^{\mathrm{e})}$ & \\
\hline \multirow{2}{*}{ B9-1025 } & $6.42^{\text {a) }}$ & $7.72^{\mathrm{a})}$ & 7.72 \\
\hline & $6.54^{\text {a) }}$ & $7.85^{\mathrm{a})}$ & 7.85 \\
\hline
\end{tabular}

a) Fish (lipid: $5 \%$ )

b) Zooplankton (lipid: $1.48 \%$ )

c) Long-nose sucker (lipid: $0.96 \%$ )

d) Lake whitefish (lipid: $2.69 \%$ )

e) Lake trout (lipid: $8.4 \%$ )
により行われた。アラスカ北部の Beluga whale の脂肪試 料を分析したところ, 雄は雌よりも濃度が高くさらに雄 は年齢とともにその濃度が増加する傾向が見られた。一 方, 雌では年齢とともにその濃度は減少するとともに, 胎児中の濃度は母体よりも10\%程度高い值を示したこと から, 胎盤経由での移動および授乳による影響が考えら れた。

\section{5. 試料の前処理法}

魚類試料における前処理の例 ${ }^{22)}$ を Fig. 2 に示す。この ように生物試料の場合には, ゲル浸透クロマトグラ フィー (以下, GPC), フロリジルカラムクロマトグラ フィー (以下, FCC), シリカゲルカラムクロマトグラ フィー（以下, SCC）を組み合わせた前処理法を基本と して, 適宜この方法を修飾する場合が一般的である。こ こで，FCCにおける Parlar 異性体 (22種) の分画例 ${ }^{92)}$ を Table 7 に示す。トキサフェンの組成を考虑すると, GC-MS 測定時に妨害成分となり得る物質は可能な限り 前処理時に分離することが望まれるが，実際には他の OCs と同一画分に溶出する。これら OCs の中で, GCMS 測定時の質量数と国内における実濃度の点から, 最

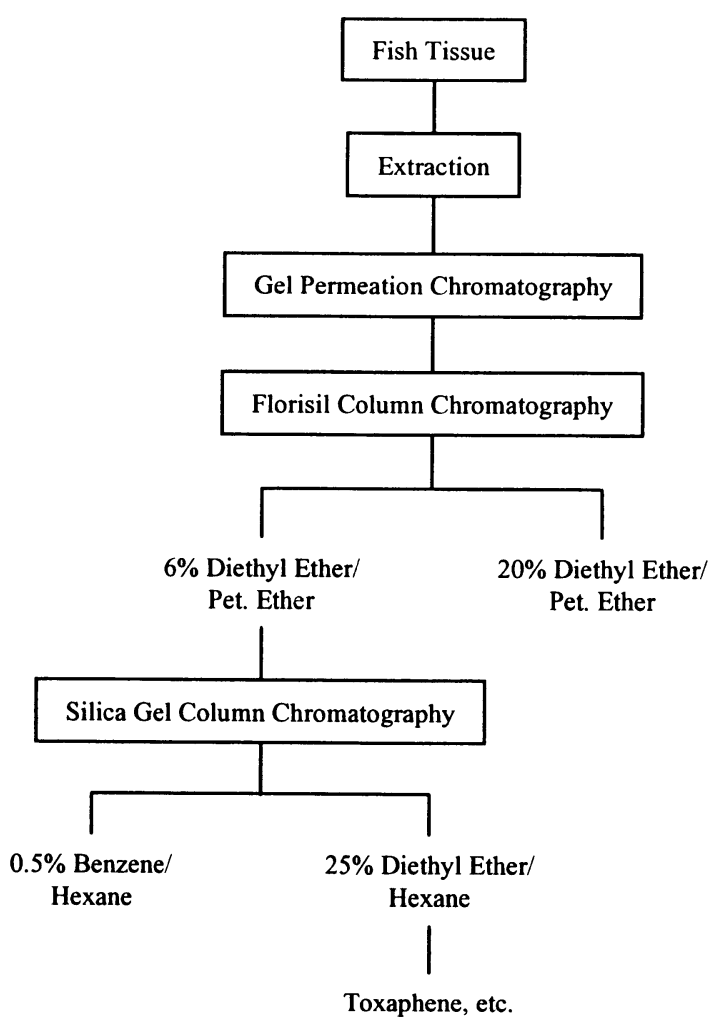

Fig. 2 Flow scheme of cleanup procedure 
も影響を及ほす物質はクロルデン類（以下，CHLs）と ポリ塩化ビフェニル類（以下, PCBs）であろう。現段階 では，OCs との定量的な分離を達成させる手法は皆無と 思われるが，SCCにおいては有用な情報が得られてい る。KrockらはSpecht らの OCs 分離法 ${ }^{150}$ 改良し, 比較 的高濃度のトキサフェンを含有すると思われる Grey Seal の脂肪試料を用いて PCBs と工業用トキサフェンの 分離を試みた ${ }^{156)}$ 。その結果, 第 1 画分としてへキサン $(48 \mathrm{~m} \ell)$, 第 2 画分としてへキサン/トルエン混合溶液 $(65: 35,50 \mathrm{~m} \ell)$ を用いることにより，第 2 画分におけ る PCBs 含有量は試料中の総 PCBs 量の $5 \%$ 未満となっ た。また，この研究において第 2 画分にPCBs が含まれ た理由として，彼らは “PCBs とトキサフェンの不十分 な分離”に起因するのではなく、“シリカゲル量の不足” を原因に挙げている。すなわち, PCBsやp, p'-DDEなど を多量に含む試料（有機塩素系剈として $1 \sim 5 \mu \mathrm{g}$ 以上, または試料中の濃度として250ppb 以上）の場合には, シ リカゲル量を増加させるか, SCCへの負荷量を減らすこ とによりこの問題は解決されると結論付けた。van der Valkらも同様な意見であり, SCCを繰り返すことで, PCBs のピーク強度が減少することをクロマトグラムの 提示とともに説明している ${ }^{66)}$ 。また, 具体的な回収率の 表示がされていないが, 彼らは魚類試料の前処理におい て, 抽出後に酸化アルミニウム $(6 \%$ 含水, $25 \mathrm{~g})$ を通過 させ，その直後にSCCを用いたことも追記しておく。

\section{6. 定量}

トキサフェンの GC-MS 測定には未だ多くの課題が残 されている。この物質の定量を複雑にさせる最大の要因 はその組成であり, 高分解能 GC-MS (以下, HRGCHRMS）と高性能キャピラリーカラムを用いても, 個々 の成分の完全な同定は極めて困難である。さらに, 現在 入手可能なトキサフェンの標準品は, 単成分の Native 標 準品が20種程度である。そのためサロゲート物質および 内標準物質として, ${ }^{13} \mathrm{C}$ ラベル化された PCBs や CHLs を
代用する例 ${ }^{93,116)}$ が多い。このような研究背景から，一部 の研究者らは工業用トキサフェンから必要とする異性体 を単離して実験に供している ${ }^{91)}$ 。実際に工業用トキサ フェンを GC-MSにより測定すると数百以上のピークが 観測されるが (Fig. 3)，環境中に残存する異性体は非生 物相で30 40種, 生物相で10種程度に限られており全濃

Table 7 Fractionation of 22 Parlar toxaphene congeners by Florisil column chromatography

\begin{tabular}{lcc}
\hline & \multicolumn{2}{c}{ Percentage of fractionation (\%) } \\
\cline { 2 - 3 } Congeners & Fr. 1 (35 ml) & Fr. 2 (38 ml) \\
& Hexane & 15\% DCM/Hexane \\
\hline Parlar 11 & 3 & 97 \\
Parlar 12 & 0 & 100 \\
Parlar 15 & 48 & 52 \\
Parlar 21 & 17 & 83 \\
Parlar 25 & 0 & 100 \\
Parlar 26 & 45 & 55 \\
Parlar 31 & 8 & 92 \\
Parlar 32 & 1 & 99 \\
Parlar 38 & 100 & 0 \\
Parlar 39 & 3 & 97 \\
Parlar 40 & 0 & 100 \\
Parlar 41 & 0 & 100 \\
Parlar 42 & 0 & 100 \\
Parlar 44 & 0 & 100 \\
Parlar 50 & 43 & 57 \\
Parlar 51 & 0 & 100 \\
Parlar 56 & 13 & 87 \\
Parlar 58 & 80 & 20 \\
Parlar 59 & 12 & 88 \\
Parlar 62 & 6 & 94 \\
Parlar 63 & 0 & 100 \\
Parlar 69 & 77 & 23 \\
\hline
\end{tabular}

Florisil: $8 \mathrm{~g}, 1.2 \%$ deactivated

DCM: Dichloromethane

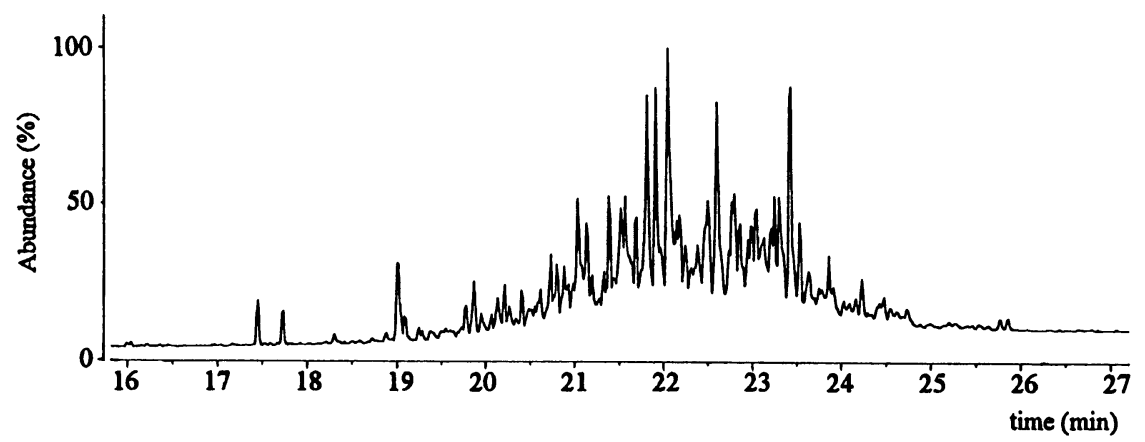

Fig. 3 Total ion chromatogram of technical toxaphene by HRGC-EI-HRMS in NIES 
度では100ppb 以下である。よって, 各媒体のクロマトグ ラム中で顕著なピークを示す, 所謂, 指標異性体を特定 することにより，それらの総量をトキサフェン量と定義 する方法もひとつの案ではある。例えば，欧州における 食品中のトキサフェン分析では, 残留性の高い 4 種の塩

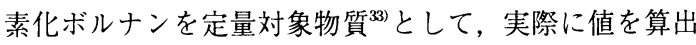
している。その一方で，アメリカ合衆国やカナダではト キサフェンは工業用トキサフェンと定義されているた め, より多くの異性体を同定する必要がある。そこで, 定量用イオンと確認用イオンを各同族体で設定して両者 の面積比と保持時間をモニタリングした上で，ある一定 の許容範囲内に収まるピークをすべて定量する方法も行 われている。ただし，実試料においては先に述べたよう に組成変化が起こっているため，工業用トキサフェンを 標準物質に用いて GC-MSによる定量操作を行うと得ら れた結果に有意差の生じる恐れがある。

\section{7. ガスクロマトグラフィー}

ガスクロマトグラフィーを利用する際に留意すべきこ とはトキサフェンの熱分解である。この物質は熱に対し て極めて不安定であるため, 熱分解が注入部やキャピラ リー表面あるいは検出器にて起こるものと推測される。 そのため，スプリット/スプリットレス注入（以下， SSL）の温度条件として $220 \sim 250^{\circ} \mathrm{C}$ 以下での使用 ${ }^{32,115,119)}$ が提唱されている。SSLの使用に伴う具体的な問題点 ${ }^{117}$ はBuserらが指摘している。彼らは工業用トキサフェン および標準品22成分の混合物を用いて SSLの検討を行っ た。その結果， 9 塩素化および10塩素化ボルナンに顕著 な挙動差が観察され, 注入部から分析カラムへの移動が 不完全であるためにこれら高塩素化体がより低い応答性 を示したものと考察した。さらに，6員環炭素上に $\mathrm{gem}-$ 塩素を持ったボルナンはSSLを用いることで特に熱分解 を受けやすいとも言及している。したがって, 注入部で のトキサフェンの滞留時間は可能な限り短くした方が好 ましく，熱分解を抑制する対策のひとつとしてオンカラ ム注入などが適しているものと思われる。Buserらもオ ンカラム注入で再測定したところ高塩素化体の応答が良 化した ${ }^{117)}$ と報告しており，仮に通常の SSLを用いる場合 でもパルスドスプリットレス注入を適用するなどの工夫 が必要であろう。ただし，リテンションギャップを接続

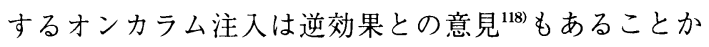
ら，その使用に際してはあらかじめ十分に検討すべきで ある。

トキサフェンの異性体分離には無極性（ジメチルポリ シロキサン相当）あるいは微極性（5％フェニル-95\% ジメチルポリシロキサン相当）のキャピラリーカラムが 汎用 ${ }^{118)}$ されてきた。環境試料において確認されるトキサ フェンの異性体は限られており，B8-1413，B9-1679,
B9-1025といった高残留性の異性体のみを測定対象とす る場合には，これら無極性あるいは微極性カラムの使用 により十分な分離が達成されるためである。しかしなが ら, Parlar Numbers の付与された主要異性体を完全に分 離するにはこれらのカラムでは困難であることから， 中極性のカラムを用いた検討が行われるようになっ た。Witteらは HT-8 (SGE 製) ${ }^{46)}$ ， Baycan-Keller らは OPTIMA $\delta-3$ (MACHEREY-NAGEL製) ${ }^{32}$ ，Karlsson ら は OV-1701（Quadrex 製) 1200をそぞれ用いてトキサ フェンの異性体分離を検討している。これより, HT-8 とOPTIMA $\delta-3$ は Parlar31から Parlar44までを完全に分 離することが可能であり，特に OPTIMA $\delta-3$ は極めて 困難とされてきたParlar42a と Parlar42b の分離も定量的 とは言えないがほほ達成した。すなわち，トキサフェン の分析にはこのような固定相をもったカラムが適してい るものと推測される。同様の検討は強極性カラムを用い ても行われているが, Oehmeらによって水酸基やシア ノプロピル基を固定相に有する強極性カラムはトキサ

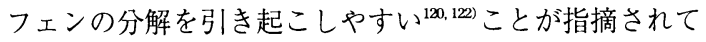
いる。

以上はいずれも単独のキャピラリーカラムを用いた検 討であるが，共溶出成分の分離を効率良く行うために多 次元ガスクロマトグラフィー（以下, MDGC) への応 用 ${ }^{24)}$ も研究されている。MDGCの優れた点はカラム連 結技術により定量目的成分のピーク分離を促進させるこ とにある。de BoerらはDB-5 (Agilent Technologies 製) と Rtx-2330 (Restek 製) を連結した多段カラムを作成 し ${ }^{123)}$ ，工業用トキサフェンおよび生物試料を分析した。 キャピラリーカラムの単独使用時に得られたクロマトグ ラムとの比較では, より多くの分離したピークが検出さ れたことからトキサフェン分析における MDGC の有用 性が示唆された。このように現段階では, 単独のキャピ ラリーカラムによる分析は測定結果に正の誤差を与える 要因となるかもしれない。しかしながら, トキサフェン のように複雑な組成であり, 利用できる単成分の標準品 が少ない物質については, 溶出順序の予測とカラムの選 択が容易ではない。MDGCを利用した研究は今後更な る継続が必要かと思われる。

エナンチオマの選択的分離もトキサフェン分析におけ る大きな課題である。この目的で使用されるカラムとし ては, tert-butyldimethylsilylated- $\beta$-cyclodextrin 修飾力 ラムが挙げられる。このカラムによる検討例は比較的多 く，トキサフェン分析にも適用 ${ }^{125-129)}$ されているが，その 中でも特に heptakis (2,3,6-tert-butyldimethylsilyl)- $\beta$ cyclodextrin 修飾カラムは塩素化ボルナンのエナンチオ マ分離に有用 ${ }^{125,127,130)}$ であることが確認された。Vetter ら は，この修飾カラムを用いて工業用トキサフェン中の 8 種の主要異性体についてエナンチオマ分離を試みた ${ }^{132)}$ 。 
その結果, 8 種すべてのエナンチオマ分離が 1 回の GC 操作により達成された。ただ, この修飾カラムの固定 相の定義は不十分であるため, 同一固定相でも分離度合 いの異なることが Oehmeらにより指摘 ${ }^{131}$ されている。 また, 分離させたエナンチオマの各ピークが結果的にそ れ以外の異性体のピークと重なってしまう可能性も高 い。いくつかの課題が依然残ってはいるが, エナンチオ マを分離する目的においてはこのような修飾力ラムは非 常に効果的であり, MDGC との組み合わせにより測定 データの信頼性がより高まるものと期待される。

\section{8. 検出器とイオン化法}

機器分析に㧍けるトキサフェンの検出法は, 主に電子 捕獲型検出器 (以下, ECD) を用いる方法と質量分析計 （以下，MS）を用いる方法に区分される。ECD は定量目 的成分の高感度な検出が可能であることから, 様々な化 学物質の同定 ${ }^{133}$ に使用されている。実際, 初期のトキサ フェン分析では GC-ECD が沉用されており,多数の研 究例 $106,134,135)$ が報告されている。ECD は選択性が質量分 析計よりも劣るため使用の際には, 常に夾雑物による干 渉を考慮する必要がある。そのため, ECDによりトキサ フェンを定量する場合には, 前処理過程で PCBsなどを 完全に除去しなくてはならないが18), 前述したように前 処理を行ってもトキサフェンはCHLsなど他の多くの OCs と同一画分に溶出する。そこで, 現在では ECD よ りも選択性に優れた MS を利用する分析法が主流となっ ている。

これまでの研究に基づくとトキサフェンの質量分析に 適用されるイオン化法には, 電子衝撃イオン化法 (以 下, EI 法) と負イオン化学イオン化法 (以下, NICI 法) が挙げられる。一般的に EI 法は他のイオン化法と比較 してフラグメンテーションが起こりやすく, 構造情報を 得やすい特徵がある。著者らは MS 条件を変更させなが ら，EI法による工業用トキサフェンのスキャン測定を 行った。その結果, いずれの場合も広範囲な質量数に及 ぶフラグメンテーションの存在を確認する反面, 分子イ オンピークを観測することができなかった。この事実は Oehme らも報告 ${ }^{118}$ しており，EI 法に起因するこのフラ グメンテーションがトキサフェンの分析をより困難なも のにすると言及している。すなわち, 通常のスペクトル 解析のように 1 価の分子イオンを直接測定することがで きず, $[\mathrm{M}-\mathrm{Cl}]^{+} や[\mathrm{M}-\mathrm{HCl}-\mathrm{Cl}]^{+}$などのフラグメントイ オンをモニタリングイオンに選定しなくてはならない。 しかしながら，実際にはこれらイオンに対しても他の同 族体由来の $[\mathrm{M}-\mathrm{Cl}]^{+}$や 1 価不飽和ボルナンなどの干渉 が起こるため, これらの干渉を受けずに測定するには分 解能20,000以上を有する質量分析計が必要 ${ }^{36)}$ とされる。 Santos らはタンデム型質量分析計を用いて EI 法にお
ける塩素化ボルナンのフラグメンテーションを解析し

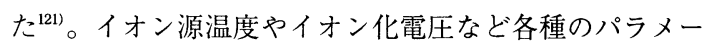
ターを最適化して実験を行ったが, 特に高質量側で強い フラグメントイオンが表れた。彼らの検討においても EI 法では分解能 20,000 以上を有する質量分析計が必要 との結論ではあるが, 分解能10,000にて測定することに より, マススペクトル上の干渉はそのほとんどが無視で きると補足している。以上のことから，EI法を用いる 場合にはHRGC-HRMS との組み合わせが望ましい。 Andrews らは分解能10,000の HRMS を用いて検討137 を 行っている。彼らは塩素化ボルナンの転位と脱塩素化の 際に生成されるジクロロトロピリウムイオンに対応した フラグメントイオンを選択イオンモニタリング（以下， SIM）により測定した。この方法は, 同族体の区別がで きないことから環境試料に含まれるトキサフェンの異性 体組成を明らかにすることは不可能であり感度も他の方 法より劣るが, 夾雑物による干渉を受けずにトキサフェ ンの総量を見積ることができる点において非常に優れて いる。Buserらは検出器にタンデム型 MS/MSを用い $て^{125} \mathrm{EI}$ 法により生体試料中のトキサフェンを定量して いる。その際の SIM 測定では $m / z=125 ， 159 ， 195$ およ び231を選定しており, 特に $m / z 125$ はすべてのトキサ フェンの異性体に特徵的なフラグメントイオンであっ た。Chanらのイオントラップ型MS/MSによる検討にお いても $m / z=125$ は主要なピークであったが, PCBs や他 の OCsのフラグメントイオンを考慮すると, $m / z=89$ が より好ましい(138) と結論付けている。

NICI 法は，EI 法におけるトキサフェンのフラグメン テーション対策として使用されるようになり近年では最 も沉用されている。このイオン化法の特徵は, 生成する 分子イオンの内部エネルギーが小さくなるのでフラグメ ンテーションが起こりにくく, 分子量に関連したピーク を強く観測できる点にある。特に, OCsではこの傾向が 顕著に表れることから, 著者らもトキサフェンに対して NICI 法を適用したところ，フラグメントイオンの大幅 な減少とそれに伴う強い分子イオンピークを観測するこ とができた。低塩素化ボルナンの感度は EI 法より劣る との意見 ${ }^{139}$ もあるが, Barrie らは塩素化ボルナンの GCMS 測定がNICI 法によってより高感度で選択性の高い測 定になっだท) と言及している。同様の見解 ${ }^{116}$ は Fowler か らも得られているが, 同時に Fowler も含めて複数の研 究者により実試料の測定における問題点も指摘されてい る。そのひとつがイオン源への酸素の混入 ${ }^{66,116,119)}$ であ る。仮にイオン源に僅かなリークが発生し酸素が混入し た場合には, 夾雑物である PCBs のフラグメント $[\mathrm{M}-\mathrm{Cl}$ $+\mathrm{O}]^{-}$および $[\mathrm{M}-\mathrm{H}+\mathrm{O}]^{-}$が生成する。このフラグメン トイオンの質量数は 7 塩素化ボルナンと接近しており, これを分離するには分解能 10,000 以上が必要 ${ }^{116)}$ であるた 
め, 低分解能 MS（以下，LRMS）におけるSIM 測定では 測定值に正の誤差が生じてしまう。したがって, MS を 検出器に用いる場合（特に, LRMS 使用時）には定期的 なリーク検査を必ず実施すべきである。

NICI 法におけるもうひとつの問題は, 相対感度係数 (以下, RRF) が個々のトキサフェン異性体間で10倍以上

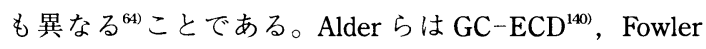
らは GC-NICI-MS ${ }^{141}$ を用いて, 米国国務省標準技術局 (以下, NIST) 作製の環境標準試料である NIST 1588 に 対してトキサフェンの分析を個別に行った。その結果, トキサフェンの総濃度として Alderらは1, $600 \mu \mathrm{g} / \mathrm{kg}$, Fowler らは $5,410 \mu \mathrm{g} / \mathrm{kg}$ と算出した。そこでAlderらは NICI-MS を用いて再測定を試みたところ，その值は $5,210 \mu \mathrm{g} / \mathrm{kg}$ となった。彼らは ECD と NICI-MSにおける 測定值の差が, 個々の異性体に対する RRF の違いに起 因敫するものだと説明している。NICI-MSにより得ら れる各異性体の RRF は ECD での值と比較してかなり大 きく変動し, 再現性に乏しい。実際に, NICI-MSにおけ る B9-1025の測定は極めて感度が不足しており ${ }^{130} ， 2-$ 位 炭素原子と 5 -位炭素原子にジクロロ基を有するボルナ ンの異性体はイオン源にて分解している恐れもある。し たがって, 標準品が得られている異性体については NICI-MSによる測定で問題はないが, トキサフェンの 総量を算出する場合には; 少なくとも確認用イオンと定 量用イオンの比率を確認して可能な限り多くの異性体を アサインすることが求められる。

\section{9. おわりに}

現在までに検討されたトキサフェンに関する分析法 は，GC-MS を利用する方法に限っても実に多様である。 前処理法拉よび定量法を規定せずにCodfish の肝油を用 いたラウンドロビン試験を実施したところ，測定值に非

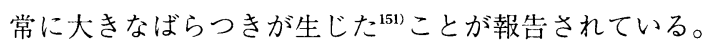
この要因のひとつに, 精度と正確さに優れた一連の分析 手法（前処理からデー夕处理に至るまで）が未だに確立 されていないことが挙げられる。この物質が国際的に規 制すべき化学物質である現状を考慮すると, 精度管理も 含めた信頼性の高い分析手法を早急に構筑する必要があ る。また，目的とするデータの質に合わせて検出器また は検出法を適宜選択することも重要であろう。環境試料 中のトキサフェンの総量を必要とするのか, 異性体の組 成情報を必要とするのかによって, 現状では利用すべき 測定手法が限定される。

\section{要 約}

トキサフェンは日本国内において農薬としての登録害 績はないが, 残留性有機污染物質であることから, 今 後, 国際的に規制される化学物質のひとつである。そこ
で,トキサフェンによる日本国内の環境污染の実態調査 を進める上で, 世界における污染状況や環境中での分解 性に関する知見をまとめ, GC-MSによる定量法につい て紹介した。環境中に残留するトキサフェンは経年変化 により本来の工業用トキサフェンとは著しく組成が異な り, 例えば，土壤中における主要な分解経路は還元脱塩 素化であり, 母乳中で高い割合を占める異性体は B81413およびB9-1679と判明した。これより，塩素が置換 した際に立体障害がなく 6 員環に歪の生じないボルナン 骨格を有する異性体が, 環境中において高い残留性を示 すことが示唆された。一方, GC-MS 測定では注入部に おける熱分解, EI 法によるフラグメンテーション, NICI 法における異性体間の相対感度係数の差に特に留意すべ きである。今後, より精度と正確さに優れた分析手法を 確立するためには, エナンチオマの選択的分離や標準物 質の合成が求められる。

\section{文 献}

1) Holmstead, R.L., Khalifa, S. and Casida, J.E.: Toxaphene composition analyzed by combined gas chromatography-chemical ionization mass spectrometry. J. Agric. Food Chem., 22, 939-944 (1974)

2) Pollock, G.A. and Kilgore, W.W.: Toxaphene. Residue Rev., 69, 87-140 (1978)

3) Saleh, M.A. and Casida, J.E.: Consistency of toxaphene composition analyzed by open tubular column gas-liquid chromatography. J. Agric. Food Chem., 25, 63-68 (1977)

4) Saleh, M.A.: Applications of New Mass Spectrometry Techniques in Pesticide Chemistry. pp34, Edited by Rosen, J.D., Wiley, New York (1987)

5) Vetter, W. and Oehme, M.: Handbook of Environmental Chemistry. vol.3. "Congener-specific analysis of toxaphene" Edited by Paasivirta, J., Springer, Berlin (1999)

6) Swackhamer, D.L., Charles, M.J. and Hites, R.A.: Quantitation of toxaphene in environmental samples using negative ion chemical ionization mass spectrometry. Anal. Chem., 59, 913-917 (1987)

7) Vetter, W. and Luckas, B.: Theoretical aspects of polychlorinated bornanes and the composition of toxaphene in technical mixtures and environmental samples. Sci. Total Environ., 160/161, 505510 (1995)

8) Jansson, B. and Wideqvist, U.: Analysis of toxaphene PCC and chlordane in biological samples by NCI mass spectrometry. Int. J. Environ. Anal. Chem., 13, 309-321 (1983) 
9) Saleh, M.A.: Capillary gas chromatography-electron impact and chemical ionization mass spectrometry of toxaphene. J. Agric. Food Chem., 31, 748-751 (1983)

10) Saleh, M.A.: Toxaphene; chemistry, biochemistry, toxicity and environmental fate. Rev. Environ. Contam. Toxicol., 118, 1-66 (1991)

11) Lennon, R.E., Hunn, J.B., Schnick, R.A. and Burress, R.M.: Reclamation of Ponds, Lakes, and Streams, with Fish Toxicants; A Review. pp99, FAO Fisheries Tech. Paper 100, Food Agric. Org. U.N., Rome (1970)

12) Casida, J.E., Holmstead, R.L., Khalifa, S., Knox, J.R., Ohsawa, T., Palmer, K.J. and Wong, R.Y.: Toxaphene Insecticide; A complex biodegradable mixture. Science, 183, 520-521 (1974)

13) U.S. Public Health Service: Toxicological profile for toxaphene. pp216, U.S. PHS, Agen. Toxic Subst. Dis. Regis.

14) Health Canada: Report on Human Health Significance of Toxaphene in Lake Superior Fish Species. Ottawa, ON: Bureau of Chemical Safety. (1995)

15) Barrie, L.A., Gregor, D., Hargrave, B., Lake, R., Muir, D.C.G., Shearer, R., Tracey, B. and Bidleman, T.F.: Arctic contaminants: Sources, occurrence and pathways. Sci. Total Environ., 122, 174 (1992)

16) McConnell, L.L., Kucklick, J.R., Bidleman, T.F. and Walla, M.D.: Long-range atmospheric transport to Lake Baikal. Chemosphere, 27, 2027-2036 (1993)

17) Hooper, N.K., Ames, B.N., Saleh, M.A. and Casida, J.E.: Toxaphene, a complex mixture of polychloroterpenes and a major insecticide, is mutagenic. Science, 205, 591-593 (1979)

18) World Health Organization: Environ. Health Criteria, 45 (1994)

19) U.S. Environmental Protection Agency: Toxaphene, intent to cancel or restrict registrations of pesticide products containing toxaphene; denial of applications for registration of pesticide products containing toxaphene; determination containing the rebuttable presumption against registration; availability of decision document. Federal Register, 47, 53784-53793 (1982)

20) Swackhamer, D.L. and McConnell, L.L.: Workgroup report on environmental transport and fate.
Chemosphere, 27, 1835-1840 (1993)

21) Wideqvist, U., Jansson, B., Olsson, M., Odsjo, T., Reutergårdh, L. and Uvemo, U.B.: Temporal trends of PCC in guillemot eggs from the Baltic. Chemosphere, 27, 1987-2001 (1993)

22) Cohen, D.B., Bowes, G.W. and Ali, S.M.: Toxaphene. pp126, California State Water Res. Control Bd., Toxic Substances Control Prog., Spec. Proj. Rep. 82-4SP (1982)

23) Albert, Lilia, personal communication, Instituto Politechnico Nacional (1980)

24) Benedek, P., Komlodi, J., Herczeg, G. and Dely, G.: Preliminary experiments aimed at developing seed lucerne pest control methods safe for bees: toxicity of field-weathered insecticide residues to honeybees. Novenytermeles, 25, 129-140 (1976)

25) Heinisch, E., Kettrup, A., Jumar, A., Klein, S., Stechert, J., Hartmann, P. and Schaffer, P.: Zu einigen Folgen der Anwendung von Toxaphene im chemischen Pflanzenschutz der ehemaligen DDR. In: Heinisch, Kettrup, Wenzel-Klein (Eds.), Schadstoffatlas Osteuropa. Ecomed, Landsberg, Germany

26) Zell, M. and Ballschmiter, K.: Baseline studies on the global pollution. II. Global occurrence of hexachlorobenzene (HCB) and polychlorocamphenes (toxaphene) (PCC) in biological samples. Fresenius Z. Anal. Chem., 300, 387-402 (1980)

27) Kucklick, J.R., McConnell, L.L., Bidleman, T.F., Ivanov, G, P. and Walla, M.D.: Toxaphene contamination in Lake Baikal's water and food web. Chemosphere, 27, 2017-2026 (1993)

28) Voldner, E.C. and Li, Y.F.: Global usage of toxaphene. Chemosphere, 27, 2073-2078 (1993)

29) Cotham, W.E. and Bidleman, T.F.: Estimating the atmospheric deposition of organochlorine contaminants to the artic. Chemosphere, 22, 165-188 (1991)

30) de Boer, J. and Wester, P.G.: Determination of toxaphene in human milk from Nicaragua and in fish and marine mammals from the northeastern Atlantic and the North Sea. Chemosphere, 27, 1879-1890 (1993)

31) Gooch, J.W. and Matsumura, F.: Toxicity of chlorinated bornane toxaphene residues isolated from great lakes lake trout salvelinus-namaycush. Arch. Environ. Contam. Toxicol., 16, 349-351 (1987)

32) Baycan-Keller, R., Oehme, M. and Galliker, B.: 
Optimization of individual column length of a tandem column system for the isomer and enantiomer selective separation of toxaphenes. Organohalogen Compounds, 35, 229-233 (1998)

33) Alder, L., Bache, K., Beck, H. and Parlar, H.: Collaborative study on toxaphene indicator compounds chlorobornanes in fish oil. Chemosphere, 35, 1391-1398 (1997)

34) Barrie, L., Bidleman, T.F., Dougherty, D., Fellin, P., Grift, N.P., Muir, D.C.G., Rosenberg, B., Stern, G. and Toom, D.: Atmospheric toxaphene in the high Arctic. Chemosphere, 27, 2037-2046 (1993)

35) Rice, C.P.: Homologue concentrations of chlorobornanes in selected samples from the Bering/Chukchi sea. Chemosphere, 27, 1937-1947 (1993)

36) Ford, W.M. and Hill, E.P.: Organochlorine pesticides in soil sediments and aquatic animals in the upper Steele Bayou watershed of Mississippi. Arch. Environ. Contam. Toxicol., 20, 161-167 (1991)

37) Hargrove, B.T., Muir, D.C.G. and Bidleman, T.F.: Toxaphene in amphipods and zooplankton from the Arctic Ocean. Chemosphere, 27, 1949-1963 (1993)

38) White, D.H., Mitchell, C.A., Kennedy, H.D., Krynitsky, A.J. and Ribick, M.A.: Elevated DDE and toxaphene residues in fishes and birds reflect local contamination in the lower Rio Grande Valley, Texas. Southwestern Natural, 28, 325-333 (1983)

39) Oehme, M., Schlabach, M., Kallenborn, R. and Haugen, J.E.: Sources and pathways of persistent polychlorinated pollutants to remote areas of the North Atlantic and levels in the marine food chain; A research update. Sci. Total Environ., 186, 13-24 (1996)

40) Schmitt, C.J., Zajicek, J.L. and Peterman, P.H.: National Contaminant Biomonitoring Program; residues of organochlorine chemicals in U.S. freshwater fish, 1976-1984. Arch. Environ. Contam. Toxicol., 19, 748-781 (1990)

41) Ford, W.M. and Hill, E.P.: Organochlorine residues in Mississippi raccoons. Jour. Wildl. Manage., 54, 591-594 (1990)

42) Muir, D.C.G., Wagemann, R., Grift, N.P., Norstrom, R.J., Simon, M. and Lien, J.: Organochlorine chemical and heavy metal contaminants in white-beaked dolphins (Lagenorhynchus albirostris) and pilot whales (Globicephala melaena) from the coast of Newfoundland. Arch. Environ. Contam. Toxicol., 17, 613-629 (1988)

43) Andersson, Ö. and Wartanian, A.: Levels of polychlorinated camphenes (toxaphene), chlordane compounds and polybrominated biphenyl ethers in seals from Swedish waters. Ambio, 21, 550-552 (1992)

44) Grubb, T.G., Wiemeyer, S.N. and Kiff, L.F.: Eggshell thinning and contaminant levels in bald eagle eggs from Arizona, 1977 to 1985. Southwestern Natural, 35, 298-301 (1990)

45) Mora, M.A.: Residues and Trends of organochlorine and polychlorinated biphenyls in birds from Texas, 1965-88. U.S. Natl. Biol. Serv., Fish Wildl. Resear. 14, 26 (1995)

46) Witte, J., Büthe, A. and Ternes, W.: Congener-specific analysis of toxaphene in eggs of seabirds from Germany by HRGC-NCI-MS using a carborane-siloxane copolymer phese (HT-8). Chemosphere, 41, 529-539 (2000)

47) Shoeib, M., Brice, K.A. and Hoff, R.M.: Airborne concentrations of toxaphene congeners at point petre (Ontario) using gas-chromatography-electron capture negative ion mass spectrometry (GCECNIMS). Chemosphere, 39, 849-871 (1999)

48) Hoff, R.M., Muir, D.C.G. and Grift, N.P.: Annual cycle of polychlorinated biphenyls and organohalogen pesticides in air in Southern Ontario. 1. Air concentration data. Environ. Sci. Technol., 26, 266275 (1992)

49) McConnell, L.L., Bidleman, T.F., Contham, W.E. and Walla, M.D.: Air concentrations of organochlorine insecticides and polychlorinated biphenyls over Green Bay, Wisconsin and the four lower Great Lakes. Environ. Pollut., 101, 391-399 (1998)

50) Glassmeyer, S.T., Brice, K.A. and Hites, R.A.: Atmospheric concentrations of toxaphene on the coast of Lake Superior. Journal of Great Lakes Research, 25, 492-499 (1999)

51) Bidleman, T.F., Alegria, H., Ngabe, B. and Green, C.: Trends of chlordane and toxaphene in ambient air of Columbia, South Carolina. Atmos. Environ., 32, 1849-1856 (1998)

52) Patton, G.W., Hinckley, D.A., Walla, M.D. and Bidleman, T.F.: Airborne organochlorines in the Canadian high arctic. Tellus B, 41, 243-255 (1989)

53) Bidleman, T.F., Cotham, W.E., Addison, R.F. and 
Zinck, M.E.: Organic contaminants in the Northwest Atlantic atmosphere. Chemosphere, 24, 13891412 (1992)

54) Swackhamer, D.L. and Hites, R.A.: Occurrence and bioaccumulation of organochlorine compounds in fishes from Siskiwit Lake, Isle Royale, Lake Superior. Environ. Sci. Technol., 22, 543-548 (1988)

55) Jantunen, L.M.M., Bidleman, T.F., Harner, T. and Parkhurst, W.J.: Toxaphene, chlordane, and other organochlorine pesticides in Alabama air. Environ. Sci. Technol., 34, 5097-5105 (2000)

56) Fingerling, G., Hertkorn, N. and Parlar, H.: Formation of spectroscopic investigation of two hexachlorobornanes from six environmentally relevant toxaphene components by reductive dechlorination in soil under anaerobic conditions. Environ. Sci. Technol., 30, 2984-2992 (1996)

57) Miskimmin, B.M., Muir, D.C.G., Schindler, D.W., Stern, G.A. and Grift, N.P.: Chlorobornanes in sediments and fish 30 years after toxaphene treatment of lakes. Environ. Sci. Technol., 29, 24902495 (1995)

58) de Boer, J., de Geus, H.-J. and Brinkman, U.A. Th.: Multidimensional GC analysis of toxaphene. Organohalogen Compounds, 26, 345-350 (1995)

59) Bidleman, T.F., Patton, G.W., Walla, M.D., Hargrave, B.T., Vass, W.P., Erickson, P., Fowler, B., Scott, V. and Gregor, D.J.: Toxaphene and other organochlorines in Arctic Ocean fauna: Evidence for atmospheric delivery. Arctic, 42, 307-313 (1989)

60) Musial, C.J. and Uthe, J.F.: Widespread occurrence of the pesticide toxaphene in Canadian east coast marine fish. Int. J. Environ. Anal. Chem., 14, 117-126 (1983)

61) Cleeman, M., Paulsen, G.B., Pritzl, G., Riget, F., Poulsen, M.E., de Boer, J. and Klungsøyr, J.: Organochlorines in sediments and biota from Greenland. Organohalogen Compounds, 32, 268271 (1997)

62) Muir, D.C.G., Wageman, R., Lockhart, W.L., Grift, N.P., Billeck, B. and Metner, D.: Environmental Studies No.42. pp64, "Heavy Metal and Organic Contaminants in Arctic Marine Fish", Indian and Northern Affairs Canada, Ottawa (1987)

63) Paasivirta, J., Rantio, T., Koistinen, J. and Vuorinen, P.J.: Studies on toxaphene in the environ- ment. II. PCCs in Baltic and Arctic Sea and lake fish. Chemosphere, 27, 2011-2015 (1993)

64) Alawi, M., Barlas, H., Hainzl, D., Burhenne, J., Coelhan, M. and Parlar. H.: A contribution to the HRGC-MS and HRGC-ECD response factors of the environmental relevant toxaphene congeners. Fresenius Environ. Bull., 3, 350-357 (1994)

65) Andersson, Ö., Linder, C.E., Olsson, M., Reutergårdh, L., Uvemo, U.B. and Wideqvist. U.: Spatial differences and temporal trends of organochlorine compounds in biota from the northwestern hemisphere. Arch. Environ. Contam. Toxicol., 17, 755-765 (1988)

66) van der Valk, F. and Wester, P.G.: Determination of toxaphene in fish from Northern Europe. Chemosphere, 22, 57-66 (1991)

67) Muir, D.C.G., Ford, C.A., Stewart, R.E.A., Smith, T.G., Addison, R.F., Zinck, M.E. and Beland, P.: Organochlorine contaminants in belugas, Delphinapterus leucas, from Canadian waters. Can. Bull. Fish Aquat. Sci., 224, 165-190 (1990)

68) Muir, D.C.G., Ford, C.A., Grift, N.P., Stewart, R.E.A. and Bidleman, T.F.: Organochlorine contaminants in narwhal (Monodon monoceros) from the Canadian Arctic. Environ. Pollut., 75, 307-316 (1992)

69) Wade, T.L., Chambers, L., Gardinali, P.R., Sericano, J.L., Jackson, T.J., Tarpley, R.J. and Suydam, R.: Toxaphene, PCB, DDT, and chlordane analyses of beluga whale blubber. Chemosphere, 34, 1351-1357 (1997)

70) Taylor, D.L., Schliebe, S. and Metsker, H.: Contaminants in blubber, liver and kidney tissue of Pacific walruses. Mar. Poll. Bull., 20, 465-468 (1989)

71) Jansson, B., Vazz, R., Blomkvist, G., Jensen, S. and Olsson, M.: Chlorinated terpenes and chlordane components found in fish, guillemot and seal from Swedish waters. Chemosphere, 8, 181190 (1979)

72) Muir, D.C.G., Ford, C.A., Grift, N.P., Metner, D.A. and Lockhart, W.L.: Geographic variation of chlorinated hydrocarbons in burbot (Lota lota) from remote lakes and rivers in Canada. Arch. Environ. Contam. Toxicol., 19, 530-542 (1990)

73) Muir, D.C.G., Ford, C.A. and Grift, N.P.: Final Report, November 1986. "PCBs and organochlorine pesticides in Broughton Island dietary samples", 
Canada: Department of Fisheries and Oceans, Winnipeg (1986)

74) Kidd, K.A., Eamer, J.E. and Muir, D.C.G.: Spatial variability of chlorinated bornanes (toxaphene) in fishes from Yukon Lakes. Chemosphere, 27, 19751986 (1993)

75) Calero, S., Fomsgaard, I., Lacayo, M.L., Martinez, V. and Rugama, R.: Toxaphene and other organochlorine pesticides in fish from Lake Xolotlan, Nicaragua. Int. J. Environ. Anal. Chem., 53, 297305 (1993)

76) Gooch, J.W. and Matsumura, F.: Evaluation of toxic components of toxaphene in Lake Michigan lake trout. J. Agric. Food Chem., 33, 844-848 (1985)

77) Glassmeyer, S.T., de Vault, D.S., Myers, T.R. and Hites, R.A.: Toxaphene in Great Lakes fish: a temporal, spatial, and trophic study. Environ. Sci. Technol., 31, 84-88 (1997)

78) Voldner, E.C. and Schroeder, W.H.: Modeling of atmospheric transport and deposition of toxaphene into the Great Lakes ecosystem. Atmos. Environ., 23, 1949-1961 (1989)

79) Hainzl, D., Burhenne, J. and Parlar, H.: Theoretical consideration of the structural variety in the toxaphene mixture taking into account recent experimental results. Chemosphere, 28, 245-252 (1994)

80) de Geus, H.-J., Besselink, H., Brouwer, A., Klungsøyr, J., McHugh, B., Nixon, E., Rimkus, G.G., Wester, P.G. and de Boer, J.: Environmental occurrence, analysis, and toxicology of toxaphene compounds. Environ. Health Persp., 107, 115-144 (1999)

81) El-Sebae, A.H., Zeid, M.A. and Saleh, M.A.: Status and environmental impact of toxaphene in the third world: A case study of African agriculture. Chemosphere, 27, 2063-2072 (1993)

82) Datta, S., Ohyama, K., Dunlap, D.Y. and Matsumura, F: Evidence for organochlorine contamination in tissues of salmonids in Lake Tahoe. Ecotox. Environ. Safe., 42, 94-101 (1999)

83) Murphy, T.J., Mullin, M.D. and Meyer, A.: Equilibration of polychlorinated biphenyls and toxaphene with air and water. Environ. Sci. Technol., 21, 155-162 (1987)

84) Isnard, P. and Lambert, S.: Aqueous solubility and $n$-octanol/water partition coefficient correla- tions. Chemosphere, 18, 1837-1853 (1989)

85) Hainzl, D., Burhenne, J., Barlas, H. and Parlar, H.: Spectroscopic characterization of environmentally relevant $\mathrm{C}_{10}$-chloroterpenes from a photochemically modified toxaphene standard. Fresenius J. Anal. Chem., 351, 271-285 (1995)

86) Andrews, P. and Vetter, W.: A systematic nomenclature system for toxaphene congeners. Part 1, Chlorinated bornanes. Chemosphere, 31, 38793886 (1995)

87) Wester, P.G., de Geus, H.-J., de Boer, J. and Brinkman, U.A. Th.: Simple nomenclature for chlorinated bornanes, bornenes and bornadienes from which structural information can be directly deduced. Chemosphere, 35, 1187-1194 (1997)

88) Nikiforov, V.A., Tribulovich, V.G. and Karavan, V.S.: On the nomenclature of toxaphene congeners. Organohalogen Compounds, 26, 393-396 (1995)

89) Coelhan, M., Fingerling, G., Angerhöfer, D. and Parlar, H.: Verhalten und Verbleib des Insektizids Toxaphene in der Umwelt. Z. Umweltchem. Ökotox., 10, 37-59 (1998)

90) Sergeant, D.B. and Onusaka, F.I.: Analysis of Trace Organics in the Aquatic Environment. pp69, "Analysis of toxaphene in environmental samples" Edited by Afgan, B.K. and Chau, A.S.Y., FL: CRC Press, Boca Raton (1989)

91) Krock, B., Vetter, W., Luckas, B. and Scherer, G.: Structure elucidation of a main heptachloro congener of toxaphene in marine organisms after isolation from Melipax ${ }^{\circledR}$. Chemosphere, 33, 1005-1019 (1996)

92) Fisk, A.T., Rosenberg, B., Cymbalisty, C.D., Stern, G.A. and Muir, D.C.G.: Octanol/water partition coefficients of toxaphene congeners determined by the "slow-stirring" method. Chemosphere, 39, 2549-2562 (1999)

93) Glassmeyer, S.T., Shanks, K.E. and Hites, R.A.: Automated toxaphene quantitation by GC/MS. Anal. Chem., 71, 1448-1453 (1999)

94) Canada, Department of National Health and Welfare: Guidelines for Canadian drinking water quality. Ottawa (1978)

95) Jensen, S.: Toxaphene. A new global environmental hazard. Kem. Tidskr., 92, 38-41 (1980)

96) Fisk, A.T., Norstrom, R.J., Cymbalisty, C.D. and Muir, D.C.G.: Dietary accumulation and depura- 
tion of hydrophobic organochlorines: Bioaccumulation parameters and their relationship with the octanol/water partition coefficient. Environ. Toxicol. Chem., 17, 951-961 (1998)

97) World Health Organization: Environ. Health Criteria, 45, 15-16 (1984)

98) Buser, H.-R., Haglund, P., Müller, M.D., Poiger, T. and Rappe, C.: Rapid anaerobic degradation of toxaphene in sewage sludge. Chemosphere, 40, 1213-1220 (2000)

99) Swackhamer, D.L., Charles, M.J. and Hites, R.A.: Toxaphene in the Great Lakes. Chemosphere, 37, 2545-2561 (1998)

100) Carvalho, F.P., Montenegro-Guillen, S., Villeneuve, J.-P., Cattini, C., Bartocci, J., Lacayo, M. and Cruz, A.: Chlorinated hydrocarbons in coastal lagoons of the Pacific Coast of Nicaragua. Arch. Environ. Contam. Toxicol., 36, 132-139 (1999)

101) Kucklick, J.R. and Baker, J.E.: Organochlorines in Lake Superior's food web. Environ. Sci. Technol., 32, 1192-1198 (1998)

102) Pearson, R.F., Swackhamer, D.L., Eisenreich, S.J. and Long, D.T.: Concentrations, accumulations, and inventories of polychlorinated dibenzo- ${ }^{-}$-dioxins and dibenzofurans in sediments of the Great Lakes. Environ. Sci. Technol., 31, 3523-3529 (1997)

103) Vetter, W., Bartha, R., Stern, G. and Tomy, G.: Enantioselective determination of two persistent chlorobornane congeners in sediment from a toxaphene-treated Yukon Lake. Environ. Toxicol. Chem., 18, 2775-2781 (1999)

104) Vetter, W. and Luckas, B.: Enantioselective determination of persistent and partly degradable toxaphene congeners in high trophic level biota. Chemosphere, 41, 499-506 (2000)

105) Geyer, H.J., Kaune, A., Schramm, K.-W., Rimkus, G., Scheunert, I., Brüggemann, R., Altschuh, J., Steinberg, C.E., Vetter, W., Kettrup, A. and Muir, D.C.G.: Predicting bioconcentration factors (BCFs) of polychlorinated bornane (Toxaphene) congeners in fish and comparison with bioaccumulation factors (BAFs) in biota from the aquatic environment. Chemosphere, 39, 655-663 (1999)

106) Kimmel, L., Angerhöfer, D., Gill, U., Coelhan, M. and Parlar, H.: HRGC-ECD and HRGC-ECNISIM-HRMS quantification of toxaphene residues by six environmentally relevant chlorobornanes as standard. Chemosphere, 37, 549-558 (1998)

107) Chan, H.M. and Yeboah, F.: Total toxaphene and specific congeners in fish from the Yukon, Canada. Chemosphere, 41, 507-515 (2000)

108) Parlar, H., Fingerling, G., Angerhöfer, D., Christ, G. and Coelhan, M.: Molecular Markers in Environmental Geochemistry. pp346-364, “Toxaphene residue composition as an indicator of degradation pathways" Edited by Eganhouse, R.P., ACS Symposium Series 671, American Chemical Society, Washington, DC (1997)

109) Vetter, W. and Scherer, G.: Persistency of toxaphene components in mammals that can be explained by molecular modeling. Environ. Sci. Technol., 33, 3458-3461 (1999)

110) Boon, J.P., Sleiderink, H.M., Helle, M.S., Dekker, M., van Schanke, A., Roex, E., Hillebrand, M.T., Klamer, H.J., Govers, B., Pastor, D., Morse, D., Wester, P.G. and de Boer, J.: The use of microsomal in vitro assay to study phase I biotransformation of chlorobornanes (Toxaphene) in marine mammals and birds. Possible consequences of biotransformation for bioaccumulation and genotoxicity. Comp. Biochem. Physiol. C, 121, 385-403 (1998)

111) Angerhöfer, D., Kimmel, L., Koske, G., Fingerling, G., Burhenne, J. and Parlar, H.: The role of biotic and abiotic degradation processes during the formation of typical toxaphene peak patterns in aquatic biota. Chemosphere, 39, 563-568 (1999)

112) Vaz, R. and Blomkvist, G.: Traces of toxaphene components in Swedish breast milk analysed by capillary GC using ECD, electron impact and negative ion chemical ionization MS. Chemosphere, 14, 223-231 (1985)

113) Newsome, W.H. and Ryan, J.J.: Toxaphene and other chlorinated compounds in human milk from northern and southern Canada: A comparison. Chemosphere, 39, 519-526 (1999)

114) Karl, H., Khandker, S. and Alder, L.: Variation of toxaphene indicator compounds in fish from single fishing grounds: conclusions for sampling. Chemosphere, 39, 2497-2506 (1999)

115) Alder, L., Beck, H., Khandker, S., Karl, H. and Lehmann, I.: Levels of toxaphene indicator compounds in fish. Chemosphere, 34, 1389-1400 (1997)

116) Fowler, B.: The determination of toxaphene in environmental samples by negative ion electron 
capture high resolution mass spectrometry. Chemosphere, 41, 487-492 (2000)

117) Buser, H.-R., Haglund, P., Müller, M.D., Poiger, T. and Rappe, C.: Discrimination and thermal degradation of toxaphene compounds in capillary gas chromatography when using split/splitless and oncolumn injection. Chemosphere, 41, 473-479 (2000)

118) Oehme, M. and Baycan-Keller, R.: Separation of toxaphene by high resolution gas chromatography. Chemosphere, 41, 461-465 (2000)

119) Bartha, R., Vetter, W. and Luckas, B.: Optimized pressure-pulse splitless injection and electron capture, negative ionization detection for the congener specific determination of compounds of technical toxaphene. Fresenius J. Anal. Chem., 358, 812-817 (1997)

120) Karlsson, H. and Oehme, M.: Comparison of retention time overlaps of toxaphene congeners on three different stationary phases in cod liver samples and consequences for quantification. Organohalogen Compounds, 28, 369-374 (1996)

121) Santos, E.J., Galceran, M.T., Caixach, J., Rivera, J. and Huguet, X.: Characterization of toxaphene by high resolution gas chromatography combined with high resolution mass spectrometry and tandem mass spectrometry. Rapid Commun. Mass Spectrom. 11, 341-348 (1997)

122) Baycan-Keller, R. and Oehme, M.: Thermal decomposition of toxaphene congeners by high resolution gas chromatographic phases. J. High Resol. Chromatogr., 21, 298-302 (1998)

123) de Boer, J., de Geus, H.-J. and Brinkman, U.A. Th.: Multidimensional gas chromatographic analysis of toxaphene. Environ. Sci. Technol., 31, 873879 (1997)

124) de Geus, H.-J., de Boer, J. and Brinkman, U.A. Th.: Multidimensionality in gas chromatography. Trends Anal. Chem., 15, 398-408 (1996)

125) Buser, H.-R. and Müller, M.D.: Isomer- and enantiomer- selective analyses of toxaphene components using chiral high-resolution gas chromatography and detection by mass spectrometry/ mass spectrometry. Environ. Sci. Technol., 28, 119-128 (1994)

126) Baycan-Keller, R. and Oehme, M.: Isomer and enantiomer specific separation of 16 toxaphene congeners by HRGC on different stationary phases. Organohalogen Compounds, 33, 1-6 (1997).
127) Kallenborn, R., Oehme, M., Vetter, W. and Parlar, H.: Enantiomer selective separation of toxaphene congeners isolated from seal blubber and obtained by synthesis. Chemosphere, 28, 89-98 (1994)

128) de Geus, H.-J., Baycan-Keller, R., Oehme, M., de Boer, J. and Brinkman, U.A. Th.: Enantiomer ratios of bornane congeners in biological samples using heart-cut gas chromatography with an enantioselective column. J. High Resol. Chromatogr., 21, 39-46 (1998)

129) Vetter, W., Klobes, U, Luckas, B. and Hottinger, G.: Enantioselective determination of toxaphene and other organochlorines on tert.-butyldimethylsilylated $\beta$-cyclodextrin. Organohalogen Compounds, 33, 63-67 (1997).

130) Vetter, W., Klobes, U., Hummert, K. and Luckas, B.: Gas chromatographic separation of chiral organochlorines on modified cyclodextrin phases and results of marine biota samples. J. High Resol. Chromatogr., 20, 85-93 (1997)

131) Oehme, M., Müller, L. and Karlsson, H.: High-resolution gas chromatographic test for the characterisation of enantioselective separation of organochlorine compounds: Application to tert.butyldimethylsilyl $\beta$-cyclodextrin. J. Chromatogr. A. 775, 275-285 (1997)

132) Vetter, W., Klobes, U., Luckas, B. and Hottinger, G.: Enantiomeric resolution of persistent compounds of technical toxaphene on $t$-butyldimethylsilylated $\beta$-cyclodextrin phases. Chromatographia, 45, 255-262 (1997).

133) Thompson, S., Budzinski, H., LeMenach, K., Letellier, $M$. and Garrigues, P.: Multi-residue analysis of polycyclic aromatic hydrocarbons, polychlorobiphenyls, and organochlorine pesticides in marine sediments. Anal. Bioanal. Chem., 372, 196 -204 (2002).

134) Walter, B. and Ballschmiter, K.: Quantitation of camphechlor-toxaphene in cod-liver oil by integration of the HRGC-ECD-pattern. Fresenius J. Anal. Chem., 340, 245-249 (1991)

135) Xu, L., Hainzl, D., Burhenne, J. and Parlar, H.: HRGC-ECD and HRGC-NICI SIM quantification of toxaphene residues in selected marine organism by environmental relevant chlorobornanes as standard. Chemosphere, 28, 237-243 (1994)

136) Lau, B., Weber, D. and Andrews, P.: GC analysis of toxaphene: A comparative study of different 
mass spectrometric techniques. Chemosphere, 32, 1021-1041 (1996)

137) Andrews, P., Newsome, W.H., Boyle, M. and Collins, P.: High resolution selective ion monitoring GC-MS determination of toxaphene in Great Lakes fish. Chemosphere, 27, 1865-1872 (1993)

138) Chan, H.M., Zhu, J. and Yeboah, F.: Determination of toxaphene in biological samples using high resolution GC coupled with ion trap MS/MS. Chemosphere, 36, 2135-2148 (1998)

139) Zhu, J., Mulvihill, M.J. and Norstrom, R.J.: Characterization of technical toxaphene using combined high-performance liquid chromatography-gas chromatography-electron capture negative ionization mass spectrometry techniques. J. Chromatogr. A, 669, 103-117 (1994)

140) Alder, L. and Vieth, B.: A congener-specific method for the quantification of camphechlor (toxaphane) residues in fish and other foodstuffs. Fresenius J. Anal. Chem., 354, 81-92 (1996)

141) Fowler, B., Hoover, D. and Hamilton, M.C.: The quantification of toxaphene in environmental samples. Chemosphere, 27, 1891-1905 (1993)

142) Atuma, S.S., Bergh, A., Nilsson, I. and Aune, M.: Toxaphene levels in salmon (Salmo salar) from the Baltic Sea. Chemosphere, 41, 517-520 (2000)

143) Henry, K.S., Kannan, K., Nagy, B.W., Kevern, N.R., Zabik, M.J. and Giesy, J.P.: Concentrations and hazard assessment of organochlorine contaminants and mercury in smallmouth bass from a remote lake in the Upper Peninsula of Michigan. Arch. Environ. Contam. Toxicol., 34, 81-86 (1998)

144) Whittle, D.M., Kiriluk, R.M., Carswell, A.A., Keir, M.J. and MacEachen, D.C.: Toxaphene congeners in the Canadian Great Lakes basin: temporal and spatial food web dynamics. Chemosphere, 40, 12211226 (2000)

145) Meylan, W.M. and Howard, P.H.: Atom/fragment contribution method for estimating octanol-water partition. J. Pharmac. Sci., 84, 83-92 (1995)

146) Glassmeyer, S.T., de Vault, D.S. and Hites, R.A.: Rates at which toxaphene concentrations decrease in lake trout from the Great Lakes. Environ. Sci. Technol., 34, 1851-1855 (2000)

147) Muir, D.C.G., Ford, C.A., Rosenberg, B., Norstrom, R.J., Simon, M. and Beland, P.: Persistent organochlorines in beluga whales (Delphinapterus leucas) from the St Lawrence River estuary-I.
Concentrations and patterns of specific PCBs, chlorinated pesticides and polychlorinated dibenzo$p$-dioxins and dibenzofurans. Environ. Pollut., 93, 219-234 (1996)

148) McCarthy, L.H., Stephens, G.R., Whittle, D.M., Peddle, J., Harbicht, S., LaFontaine, C. and Gregor, D.J.: Baseline studies in the Slave River, NWT, 1990-1994: Part II. Body burden contaminants in whole fish tissue and livers. Sci. Total Environ., 197, 55-86 (1997)

149) Cleeman, M., Riget, F., Paulsen, G.B., de Boer, J., Klungsøyr, J. and Aastrup, P.: Organochlorines in sediments and biota from Greenland. Sci. Total Environ., 245, 173-185 (2000)

150) Maruya, K.A. and Lee, R.F.: Aroclor 1268 and toxaphene in fish from a southeastern U.S. estuary. Environ. Sci. Technol., 32, 1069-1075 (1998)

151) Andrews, P., Headrick, K., Pilon, J.-C., Lau, B. and Weber, D.: An interlaboratory round robin study on the analysis of toxaphene in a cod liver oil standard reference material. Chemosphere, 31, 4393-4402 (1995)

152) Herzke, D., Kallenborn, R. and Nygård, T.: Organochlorines in egg samples from Norwegian birds of prey: Congener-, isomer- and enantiomer specific considerations. Sci. Total Environ., 291, 59-71 (2002)

153) Hackenberg, R., Looser, R., Froescheis, O. and Ballschmiter, K.: Trends of POPs in biota of the Atlantic Ocean-samples of 1981/1982 reanalyzed and characterized with GC/ECD, GC/EI-MSD and GC/NCI-MSD. Organohalogen Compounds, 56, 495-498 (2002)

154) Arend, M.W., Jarman, W.M. and Ballschmiter, K.: Organohalogen POPs in fish of the Northern Pacific. Organohalogen Compounds, 58, 437-440 (2002)

155) Specht, W. and Tillkes, M.: Gaschromatographische Bestimmung von Rückständen an Pflanzenbehandlungsmitteln nach Clean-up über Gel-Chromatographie und Mini-Kieselgel-Säulen-Chromatographie. Fresenius Z. Anal. Chem., 322, 443-455 (1985)

156) Krock, B., Vetter, W. and Luckas, B.: PCB/ toxaphene group separation on silica prior to congener specific determination of toxaphene residues in fish and other samples by GC/ECD. Chemosphere, 35, 1519-1530 (1997) 